\title{
Short-term variability of photosynthetic parameters and particulate and dissolved primary production in the Alboran Sea (SW Mediterranean)
}

\author{
Xosé Anxelu G. Morán*, Marta Estrada \\ Departament de Biologia Marina i Oceanografia, Institut de Ciències del Mar, CSIC, Pg. Joan de Borbó, s/n, 08039 Barcelona, Spain
}

\begin{abstract}
The short-term variability of photosynthesis-irradiance $(P-E)$ relationships and integrated primary production at 3 stations (Stns A, B, C in a coastal-offshore gradient) located across the Western Alboran Sea Gyre (SW Mediterranean) were investigated during a High Frequency Flux Experiment (1 to 16 May 1998). Photosynthetic production of total, particulate and dissolved organic carbon (TOC, POC and DOC respectively) was considered separatedly in 34 experiments. Photosynthetic parameters were calculated for TOC and POC data. For POC measurements, maximum photosynthetic rate $\left(P_{\mathrm{m} \text { POC }}^{\mathrm{B}}\right)$ and the initial slope of the $P$ - $E$ curve $(\alpha)$ varied between 0.59 and $6.25 \mathrm{mg} \mathrm{C}$

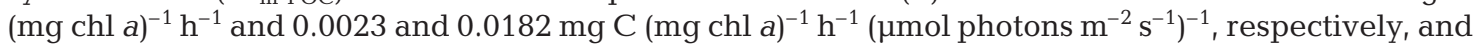
were significantly correlated, showing a similar decrease with depth. No photoinhibition was detected at any depth and the light saturation parameter $\left(E_{k}\right)$ was on average $251 \mu \mathrm{mol}$ photons $\mathrm{m}^{-2} \mathrm{~s}^{-1}$, suggesting that phytoplankton assemblages were acclimated to high irradiance levels in the whole area. Percent extracellular release (PER) obtained for each experimental irradiance $\left(\mathrm{PER}_{E}=\mathrm{DOC} /\right.$ $[\mathrm{POC}+\mathrm{DOC}]$ ) showed an inverse relationship with irradiance when data from all the $P$ - $E$ experiments were pooled. A light-saturated chl a-normalized DOC production rate $\left(P_{\mathrm{m}}^{\mathrm{B}} \mathrm{DOC}\right)$ was calculated as $P_{\mathrm{m} \text { TOC }}^{\mathrm{B}}-P^{\mathrm{B}}{ }_{\mathrm{m} \text { POC, }}$ and $\mathrm{PER}_{\mathrm{m}}$ values calculated as $P_{\mathrm{m} \text { DOC }}^{\mathrm{B}} / P_{\mathrm{m}}^{\mathrm{B}}$ TOC tended to increase with depth. Integrated particulate and total primary production varied considerably (23- and 35-fold, respectively), but tended to decrease along a coastal-offshore gradient. During the cruise, a subsurface phytoplankton bloom was advected into Stn A, increasing primary production rates up to $1 \mathrm{~g} \mathrm{C} \mathrm{m}^{-2} \mathrm{~d}^{-1}$. Average particulate primary production was $632 \mathrm{mg} \mathrm{C} \mathrm{m}^{-2} \mathrm{~d}^{-1}$ at Stn $\mathrm{A}, 388 \mathrm{mg} \mathrm{C} \mathrm{m}^{-2} \mathrm{~d}^{-1}$ at Stn B and $330 \mathrm{mg} \mathrm{C} \mathrm{m}^{-2}$ $\mathrm{d}^{-1}$ at Stn C, with dissolved primary production ranging from 4 to $44 \%$ of total values. Integrated primary production was significantly correlated with surface chl a but not with integrated chl $a$. This finding has implications for the estimation of regional primary production based on remote sensing of near-surface pigments. Altogether, the results confirmed that the high hydrodynamism of the Alboran Sea was associated with marked biological variability and episodic high primary production events.
\end{abstract}

KEY WORDS: Phytoplankton $\cdot P$-E relationships $\cdot$ Short-term variability $\cdot$ Primary production $\cdot$ DOC $\cdot$ Upwelling

\section{INTRODUCTION}

Over the past few decades, the amount of available data on aquatic photosynthesis has increased enormously. However, detailed studies of its spatio-tem-

\footnotetext{
*Present address: Instituto Español de Oceanografia, Centro Oceanográfico de Xixón, Camin de L'Arbeyal, s/n, 33212 Xixón, Spain. E-mail: xelu@icm.csic.es
}

poral variability are still needed in order to obtain more accurate estimates of primary productivity in many marine regions. One of the tools for assessing differences in the activity of phytoplankton is the study of photosynthesis-irradiance $(P-E)$ relationships. $P$-E curves are widely used for understanding the physiology and ecology of phytoplankton assemblages (e.g. Platt et al. 1980, Sakshaug et al. 1997) and are specially suitable for meso- and basin-scale 
studies because they are less demanding of ship time than other methods. Moreover, the photosynthetic parameters describing the $P-E$ relationships are required for the development of models aimed at deriving primary production from remotely sensed near-surface pigments (Platt \& Sathyendranath 1988, Longhurst et al. 1995). The lack of information on the spatial and temporal variability of photosynthetic parameters may be a serious constraint for the accuracy of currently used models of primary production in the ocean (Behrenfeld \& Falkowski 1997a, Marañón \& Holligan 1999). Often, single time data of primary production are taken as representative for extended periods, without information on their variability at shorter time scales.

The Alboran Sea occupies a key geographical position in the Mediterranean and presents an intense hydrodynamism. The water circulation in the Alboran Sea (Minas et al. 1991, Tintoré et al. 1991) is characterized by 2 anticyclonic gyres of ca $100 \mathrm{~km}$ in diameter, the Western and Eastern Alboran Sea Gyres, which occupy the respective sub-basins and are easily seen in sea surface temperature satellite images. These quasi-persistent gyres (Heburn \& La Violette 1990) are formed by the superficial inflow of Atlantic water which crosses the Strait of Gibraltar and gradually mixes with the resident Mediterranean waters, creating the so-called Modified Atlantic Water (MAW). In the northern part of the Western Alboran Gyre, the frontal zone formed at the boundary of the MAW jet and the saltier (>37.5) Mediterranean waters presents intermittent nutrient upwelling into the upper layers of the water column (Coste et al. 1988, Packard et al. 1988, Perkins et al. 1990, Minas et al. 1991). This upwelling has been associated with enhanced plankton productivity, but very few studies have reported primary production rates. Minas et al. (1991) carried out one of the few attempts to estimate primary production within the Western Alboran Gyre using an approximation based on nitrate consumption over time. The rate of new primary production thus obtained ( $635 \mathrm{mg} \mathrm{C} \mathrm{m}^{-2} \mathrm{~d}^{-1}$ ) was slightly higher than the average for other Mediterranean areas (e.g. Sournia 1973, Estrada 1981, Platt 1985, Estrada et al. 1993), but below the expected value for a high productivity site (cf. estimates, within the jet of MAW further east, in Lohrenz et al. 1988b). A number of recent papers have reported elevated biomass of planktonic organisms in the area (e.g. Jiménez et al. 1987, Rodríguez et al. 1994, 1998), but only Fernández et al. (1994) and Videau et al. (1994) included direct measurements of primary production in the Alboran Sea, across the Almería-Oran front in the eastern sub-basin (Tintoré et al. 1991). Due to the episodic nature of the physical forcing in the entire basin, the position of the MAW-
Mediterranean water front fluctuates largely at short time scales (Perkins et al. 1990).

This paper presents an investigation of the shortterm temporal variations of phytoplanktonic photosynthesis at 3 repeatedly sampled stations, located across the Western Alboran Gyre, during a High Frequency Flux Experiment (HFFE) conducted in May 1998. The aim of the cruise, as part of the European Union MTPII Project MAss Transfer and Ecosystem Response (MATER), was to study the high frequency processes controlling the pelagic-benthic coupling in the northern part of the gyre. $P-E$ relationships were investigated and the derived photosynthetic parameters were used to obtain daily integrated primary production. $P-E$ experiments have seldom tried to differentiate between particulate and dissolved primary production (Sakshaug et al. 1997), although the release of dissolved compounds by phytoplankton can significantly contribute to total primary production (Norrman et al. 1995, Biddanda \& Benner 1997) and provide substrates readily assimilable by heterotrophic bacteria (Baines \& Pace 1991, Amon \& Benner 1994). In our P-E experiments, we performed direct measurements of the extracellular release of photosynthetic carbon and considered simultaneously total, particulate and dissolved organic carbon (TOC, POC and DOC respectively) production. To our knowledge, only Fernández et al. (1994) had previously dealt with phytoplanktonic DOC release in this marine area. Their conclusion, of a higher contribution of extracellular release to total primary production in the more oligotrophic areas of the Alboran Sea, was addressed during this cruise. In addition, the effect of irradiance on the relative importance of phytoplanktonic DOC production was investigated. To date, systematic studies on the relationships between irradiance and release of photosynthate have been almost exclusively carried out with algal cultures (Verity 1981, Zlotnik \& Dubinsky 1989). The $P-E$ data set obtained here allowed for an assessment of these relationships for natural phytoplankton assemblages.

\section{MATERIAL AND METHODS}

The experiments were conducted during the MTP-IIMATER/HESP/04-98 cruise on board the RV 'Hespérides' from 2 to 13 May 1998. A total of $34 P$-E experiments (see Table 1 for details) were performed at 3 stations: Stn A ( $36^{\circ} 23^{\prime} \mathrm{N}, 4^{\circ} 15^{\prime} \mathrm{W}, 664 \mathrm{~m}$ depth), Stn B $\left(36^{\circ} 14^{\prime} \mathrm{N}, 4^{\circ} 15^{\prime} \mathrm{W}, 984 \mathrm{~m}\right.$ depth$)$ and $\mathrm{Stn} \mathrm{C}\left(36^{\circ} 0^{\prime} \mathrm{N}\right.$, $4^{\circ} 15^{\prime} \mathrm{W}, 1320 \mathrm{~m}$ depth), located along a coastaloffshore gradient crossing the northern part of the Western Alboran Gyre (Fig. 1A). The stations were visited 4 times during the cruise and sampled before noon (mostly between 09:00 and 10:00 h GMT). In 
addition, an afternoon sample was taken during the first visit to all stations and the fourth visit to Stns A and C. Hereafter, the $n$th visit to $\mathrm{Stn} X$ is represented as Stn Xn (e.g. Stns A1, C4b), with 'b' standing for the afternoon sample.

Optics and hydrography. Vertical profiles of photosynthetically active radiation (PAR, 400 to $700 \mathrm{~nm}$ ) were obtained immediately after water sampling with a Li-Cor spherical quantum sensor attached to a Seabird 25 CTD system. Vertical light attenuation coefficients $(K)$ were calculated every $10 \mathrm{~m}$, instead of using the whole profile, due to the marked changes of slope of the log-transformed data versus depth. Incident irradiance was continuously measured with a pyranometer connected to a Li-Cor LI-1000 data logger. A Neil Brown Mark III CTD was used to obtain vertical profiles of temperature, salinity and density. The depth of the upper mixed layer $\left(Z_{\text {uml }}\right)$ was determined as the depth where the change in density $\left(\sigma_{t}\right)$ was $\geq 0.05 \mathrm{~kg} \mathrm{~m}^{-3}$ over a $5 \mathrm{~m}$ depth interval (Mitchell \& Holm-Hansen 1991). Water samples for nutrient and biological determinations were collected at 10 to 11 discrete depths with 121 Niskin bottles from a rosette sampler attached to the CTD. Samples for nutrient analysis were immediately frozen and concentrations of nitrate, nitrite, phosphate and silicate were determined on unfiltered samples in the laboratory with a Technicon autoanalyzer.

Chlorophyll a (chl a) concentration. For the determination of total chl a concentration, samples of $100 \mathrm{ml}$ were filtered onto Whatman GF/F filters. In most experiments, size-fractionation of chl a $(<20,>5$ and $<2 \mu \mathrm{m}$ ) was also carried out. Detailed information on methods and results will be given in Arin et al. (unpubl.). All filters were $25 \mathrm{~mm}$ in diameter and differential pressures were kept below 200 mm Hg. Pigments were extracted in acetone for $24 \mathrm{~h}$ in the dark at $4{ }^{\circ} \mathrm{C}$ prior to fluorescence measurement without acidification with a Turner Designs fluorometer (Yentsch \& Menzel 1963). Calibration was made comparing the fluorescence readings with measurements of chl a concentration carried out with a spectrophotometer.

$\boldsymbol{P}-\boldsymbol{E}$ relationships. At each station, water was taken from 2 depths, chosen to represent the upper mixed layer ('surface' samples), and the deep chlorophyll maximum (DCM) if present, or the part of the euphotic zone located below the pycnocline ('deep' samples). Sometimes, the upper mixed layer was deeper than the photic zone (e.g. Stn C3) and the deep sample was chosen at an arbitrarily intermediate depth. The DCM was located between 20 and $50 \mathrm{~m}$ depth. Fourteen light and 1 dark (covered with aluminium foil) sterile polystyrene tissue culture bottles (Corning) containing $70 \mathrm{ml}$ water samples were incubated for each experiment and depth, in closed linear incubators with cir-
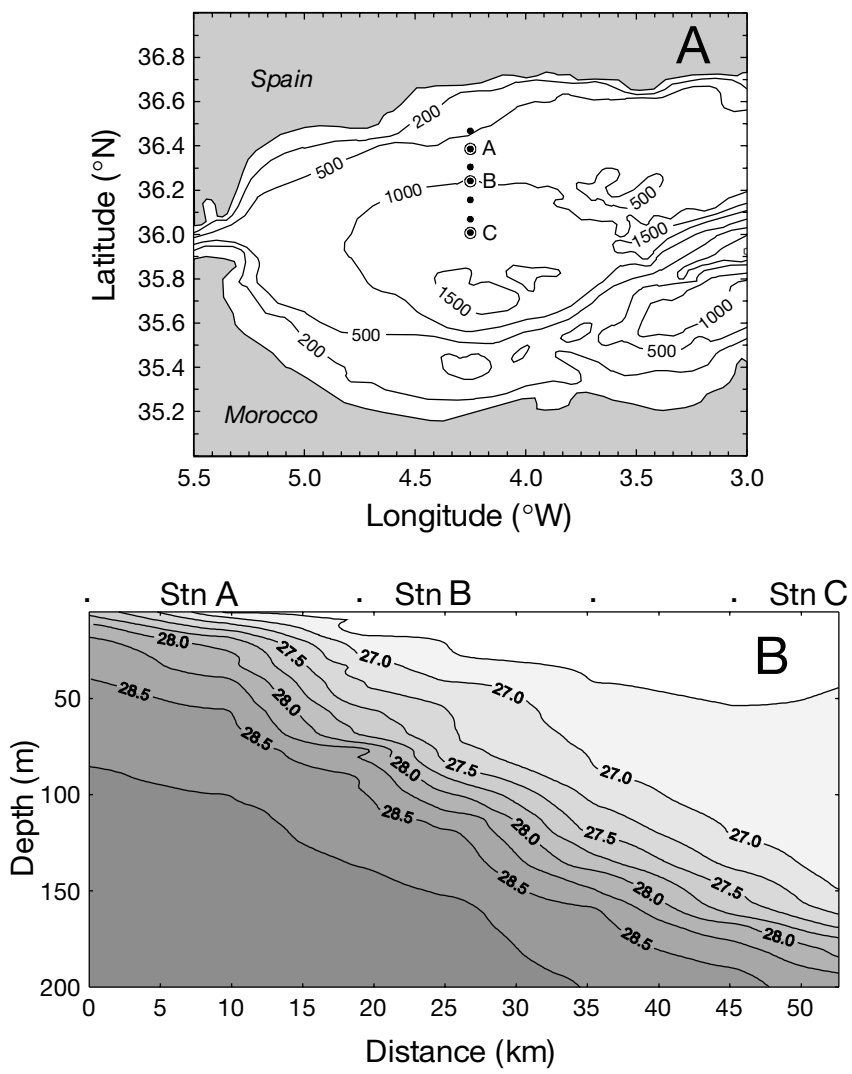

Fig. 1. (A) Location of the 3 repeatedly sampled Stns A, B and $\mathrm{C}$ and the stations of the transect shown in (B). (B) Distribution of density $\left(\sigma_{\mathrm{t}}, \mathrm{kg} \mathrm{m}^{-3}\right)$ along the transect carried out between 10 and 11 May 1998

culating water at the in situ sampling temperature $\left( \pm 0.5^{\circ} \mathrm{C}\right)$. Before starting the experiments, all bottles were spiked with 6.37 to $9.31 \mu \mathrm{Ci}$ (2.36 to $\left.3.44 \times 10^{5} \mathrm{~Bq}\right)$ of ${ }^{14} \mathrm{C}$-bicarbonate (The International Agency for ${ }^{14} \mathrm{C}$ Determination, VKI, Denmark). Incubations lasted for ca 2 to $3 \mathrm{~h}$. Illumination was provided by Phillips halogen lamps $(50 \mathrm{~W})$. The irradiance level at each position was directly measured with an Illuminova (Sweden) spherical PAR light-sensor placed inside a bottle. An intercalibration with a spherical Li-Cor quantum sensor proved that both sensors gave similar values. Values ranged from 5.4 to $1515 \mu \mathrm{mol}$ photons $\mathrm{m}^{-2} \mathrm{~s}^{-1}$ for the incubator with the more superficial samples, and from 8.5 to $880 \mu \mathrm{mol}$ photons $\mathrm{m}^{-2} \mathrm{~s}^{-1}$ for the incubator with the deeper ones. The desired attenuation of the irradiance received by the bottles was achieved by using several neutral density filters.

At the end of the incubation, subsamples were taken for determination of labelled TOC, POC and DOC, except at Stns A2, B2 and C2, in which only TOC and POC were measured. DOC was defined as the fraction passing a Millipore GSWP $0.22 \mu \mathrm{m}$ filter (mixed cellulose esters, $25 \mathrm{~mm}$ in diameter). Subsamples of $5 \mathrm{ml}$ 
each were taken for TOC and DOC. The remaining $60 \mathrm{ml}$ were filtered onto another $0.22 \mu \mathrm{m}$ filter for determination of labelled POC. The vacuum pressure was always kept below $80 \mathrm{~mm} \mathrm{Hg}$. Labelled DOC in the water sample was considered as 'dissolved primary production' originating from phytoplanktonic photosynthetic activity, but it may derive not only from dissolved organic matter released by phytoplankton but also from protozoan sloppy feeding or cellular lysis (Nagata 2000). The measurement of labelled DOC at the end of the incubation can cause an underestimation of the total phytoplanktonic DOC production if heterotrophic bacteria are simultaneously removing it. Therefore, the estimated DOC production rate should be considered as a minimum approximation. This procedure implicitly assumes linear increase in labelled DOC during the incubation period (Lancelot 1979, Morán et al. in press). The time elapsed before observing a departure from linearity during a ${ }^{14} \mathrm{C}$ primary production experiment has been shown to be very variable (e.g. from minutes to hours, Lancelot 1979, Coveney 1982), but based on previous experiments in the NW Mediterranean (Morán \& Estrada unpubl. data) linearity could be assured for a minimum period of $2 \mathrm{~h}$. In any case, we assumed that the potential underestimation did not mask the general trends in calculated DOC production rates.

Filters were fumed with concentrated $\mathrm{HCl}$ for ca $12 \mathrm{~h}$, and TOC and DOC samples were acidified with $1 \mathrm{ml}$ $\mathrm{HCl} 1 \mathrm{M}$ and left open in an orbital shaker for at least $6 \mathrm{~h}$ in order to remove inorganic ${ }^{14} \mathrm{C}$. This time span has proven sufficient to eliminate inorganic label in previous tests. Radioactivity was measured in a Beckman LS6000 (LL) liquid scintillation counter, and disintegrations $\mathrm{min}^{-1}(\mathrm{dpm})$ were calculated with the external standard method. Before further calculations, dark bottle values of labelled TOC, POC and DOC were subtracted from the light bottle values for correction of non-photosynthetic uptake of carbon. Dark bottle values were on average $74 \pm 31 \mathrm{SD} d \mathrm{pm}$ for $\mathrm{PO}^{14} \mathrm{C}$, $71 \pm 11 \mathrm{dpm}$ for $\mathrm{TO}^{14} \mathrm{C}$ and $82 \pm 16 \mathrm{dpm}$ for $\mathrm{DO}^{14} \mathrm{C}$. When considering all the experiments, dpm for samples incubated in the light were on average $231 \pm$ $185 \%$ SD higher than the corresponding dark value for TOC, and $28 \pm 15 \%$ higher for DOC. These differences between light and dark bottles were significant (paired $t$-test for experimental means: $\mathrm{p}<0.00001 ; \mathrm{n}=34$ for TOC $; \mathrm{p}=0.0008, \mathrm{n}=28$ for DOC).

POC and TOC measurements were initially fitted to the exponential model of Platt et al. (1980) using nonlinear least-squares regression (KaleidaGraph software):

$$
P^{\mathrm{B}}=P_{\mathrm{s}}^{\mathrm{B}}\left[1-\exp \left(-\alpha E / P_{\mathrm{s}}^{\mathrm{B}}\right)\right]\left[\exp \left(-\beta E / P_{\mathrm{s}}^{\mathrm{B}}\right)\right]
$$

where $P^{\mathrm{B}}\left[\mathrm{mg} \mathrm{C}(\mathrm{mg} \mathrm{chl} \mathrm{a})^{-1} \mathrm{~h}^{-1}\right]$ is the chl a-normalized photosynthetic rate, $P_{\mathrm{s}}^{\mathrm{B}}\left[\mathrm{mg} \mathrm{C}(\mathrm{mg} \mathrm{chl} \mathrm{a})^{-1} \mathrm{~h}^{-1}\right]$ is the maximum chl a-normalized photosynthetic rate without photoinhibition, $\alpha$ [mg C (mg chl a) $)^{-1} \mathrm{~h}^{-1}(\mu \mathrm{mol}$ photons $\left.\mathrm{m}^{-2} \mathrm{~s}^{-1}\right)^{-1}$ ] is the initial slope of the $P$-E curve and $\beta$ (same units as $\alpha$ ) is the photoinhibition parameter. As fitted $\beta$ values were 0 in all cases (see 'Results'), $P^{\mathrm{B}}$ in Platt et al.'s model was equivalent to $P^{\mathrm{B}}$ in the model proposed by Webb et al. (1974):

Table 1. Sampling dates, times and depths of the $P$-E experiments. Also shown are the depths of the upper mixed layer $\left(Z_{\mathrm{uml}}\right)$, the euphotic zone $\left(Z 1 \% E_{0}\right)$ and the nutricline for nitrate $\left(Z \mathrm{NO}_{3}\right)$ and phosphate $\left(Z \mathrm{PO}_{4}\right)$, and the mean irradiance within the upper mixed later $\left(E_{\mathrm{uml}}\right)$. Details explained in the text. -: not determined. Low $E_{\mathrm{uml}}$ values for Stns C3, C4 and C4b were largely due to cloudy conditions

\begin{tabular}{|c|c|c|c|c|c|c|c|c|}
\hline Stn & $\begin{array}{l}\text { Date } \\
(1998)\end{array}$ & $\begin{array}{l}\text { Time } \\
\text { (GMT) }\end{array}$ & $\begin{array}{l}\text { Depth } \\
\text { (m) }\end{array}$ & $\begin{array}{l}Z_{\mathrm{uml}} \\
(\mathrm{m})\end{array}$ & $\begin{array}{l}Z 1 \% E_{0} \\
\quad(\mathrm{~m})\end{array}$ & $\begin{array}{l}Z \mathrm{NO}_{3} \\
(\mathrm{~m})\end{array}$ & $\begin{array}{l}Z \mathrm{PO}_{4} \\
(\mathrm{~m})\end{array}$ & $\begin{array}{c}E_{\mathrm{uml}} \\
\left(\mu \mathrm{mol} \text { photons } \mathrm{m}^{-2} \mathrm{~s}^{-1}\right)\end{array}$ \\
\hline A1 & 2 May & 09:40 & 5,63 & 35 & 54 & 26 & 31 & 229 \\
\hline$A 1 b$ & 2 May & 16.25 & 30,80 & 33 & - & - & - & - \\
\hline B1 & 3 May & 09:08 & 5,35 & 36 & 53 & 51 & 150 & 149 \\
\hline B1b & 3 May & $16: 50$ & 30,80 & 34 & - & - & - & - \\
\hline $\mathrm{C} 1$ & 4 May & 10:00 & 5,80 & 65 & 51 & 72 & 68 & 162 \\
\hline $\mathrm{C} 1 \mathrm{~b}$ & 4 May & $16: 10$ & 30,80 & 63 & - & - & - & - \\
\hline A2 & 5 May & 09:30 & 25,50 & 31 & 43 & $<5$ & $<5$ & 235 \\
\hline B2 & 6 May & 09:40 & 25,50 & 29 & 50 & 5 & $<5$ & 271 \\
\hline $\mathrm{C} 2$ & 7 May & 09:05 & 35,50 & 11 & 49 & 115 & 126 & 442 \\
\hline A3 & 8 May & $11: 50$ & 15,50 & 9 & 35 & 7 & 12 & 423 \\
\hline B3 & 9 May & 09:40 & 25,50 & 14 & 61 & 43 & 53 & 318 \\
\hline C3 & 10 May & 08:10 & 5,55 & 133 & 56 & 105 & 149 & 37 \\
\hline A4 & 11 May & 08:00 & 5,45 & 7 & 42 & $<5$ & 6 & 220 \\
\hline $\mathrm{A} 4 \mathrm{~b}$ & 11 May & $16: 18$ & 5,40 & 5 & 39 & - & - & 282 \\
\hline B4 & 12 May & 08:40 & 5,25 & 9 & 55 & 8 & 5 & 459 \\
\hline $\mathrm{C} 4$ & 13 May & $10: 15$ & 5,50 & 32 & 58 & 71 & 80 & 31 \\
\hline $\mathrm{C} 4 \mathrm{~b}$ & 13 May & $15: 05$ & 5,35 & 12 & 63 & - & - & 54 \\
\hline
\end{tabular}




$$
P^{\mathrm{B}}=P_{\mathrm{m}}^{\mathrm{B}}\left[1-\exp \left(-\alpha E / P_{\mathrm{m}}^{\mathrm{B}}\right)\right]
$$

where $P_{\mathrm{m}}^{\mathrm{B}}\left[\mathrm{mg} \mathrm{C}(\mathrm{mg} \mathrm{chl} \mathrm{a})^{-1} \mathrm{~h}^{-1}\right]$ is the maximum chl a-normalized photosynthetic rate. The saturating irradiance or light saturation parameter $\left(E_{k}\right)$ was estimated as $P^{\mathrm{B}} / \alpha$.

Once $P_{\mathrm{m}}^{\mathrm{B}}$ was calculated for TOC and POC data $\left(P_{\mathrm{m}}^{\mathrm{B}}\right.$ ${ }_{\text {TOC, }} P_{\mathrm{m} \text { POC }}^{\mathrm{B}}$, a light-saturated chl a-normalized photosynthetic rate for the dissolved fraction $\left(P_{\mathrm{m} \text { DOC }}^{\mathrm{B}}\right)$ was calculated as

$$
P_{\mathrm{m} \mathrm{DOC}}^{\mathrm{B}}=P_{\mathrm{m} \text { TOC }}^{\mathrm{B}}-P_{\mathrm{m} \text { POC }}^{\mathrm{B}}
$$

Integrated primary production. The $P-E$ parameters $\left(P^{\mathrm{B}}{ }_{\mathrm{m}} \alpha\right)$, together with the depth profiles of PAR and chl a down to $100 \mathrm{~m}$ depth, and the hourly irradiance, were used to estimate the daily integrated primary production, both the total ( $\mathrm{PP}_{\text {int }}$ TOC) and the particulate $\left(\mathrm{PP}_{\text {int }} \mathrm{POC}\right)$, with the trapezoidal method. Two procedures of integration (no. 1 and no. 2) were applied to POC- and TOCderived photosynthetic parameters. In procedure no. 1, the $P$-E parameters of the most superficial sample were assumed to be representative of the phytoplankton assemblages of the upper layer down to the beginning of the DCM, and those from the DCM were in turn assumed to be representative of the phytoplankton assemblages of the rest of the water column, down to $100 \mathrm{~m}$. A discrete cut-off between both situations was made by visually estimating the depth of the steepest change in the chl a profile. In procedure no. $2, P^{\mathrm{B}}$ and $\alpha$ were interpolated by linear regression between the surface and deep values, to estimate values at all the depths where chl a was measured.

Statistical analyses other than $P$ - $E$ curve fitting were performed with the Statistica software package. Data of chl a and $\mathrm{PP}_{\text {int }}$ were $\log$-transformed to attain normality and homogeneity of variances.

\section{RESULTS \\ Optics and hydrography}

The mean total daily incident irradiance during the cruise was $35.4 \mathrm{~mol}$ photons $\mathrm{m}^{-2}$ $\mathrm{d}^{-1}$ (range 10.1 to 49.6 ). The vertical light attenuation coefficients $(K)$ for all $10 \mathrm{~m}$ depth intervals ranged from 0.047 to $0.237 \mathrm{~m}^{-1}$. Using these $K$ values, the depth of the euphotic layer $\left(Z 1 \% E_{0}\right.$, i.e. the depth with $1 \%$ of the irradiance level at the surface) was estimated (Table 1). Average values were $44 \pm 8 \mathrm{~m} \mathrm{SD}$ at Stn A, $55 \pm 5 \mathrm{~m}$ at Stn B and $54 \pm 4 \mathrm{~m}$ at Stn C. The mean daily irradiance in the upper mixed layer (see below) was generally well above $100 \mu$ mol photons $\mathrm{m}^{-2}$ $\mathrm{d}^{-1}$ for all the experiments performed at Stns A and B, but less than $50 \mu \mathrm{mol}$ photons $\mathrm{m}^{-2} \mathrm{~d}^{-1}$ for the experiments at Stns C3, C4 and C4b (Table 1).

The depth profiles of temperature, salinity and density for visits 1 through 4 to the 3 stations are shown in Fig. 2. A temporal trend towards a shoaling of the upper mixed layer $\left(Z_{\text {uml }}\right)$ was observed for the consecutive vis-
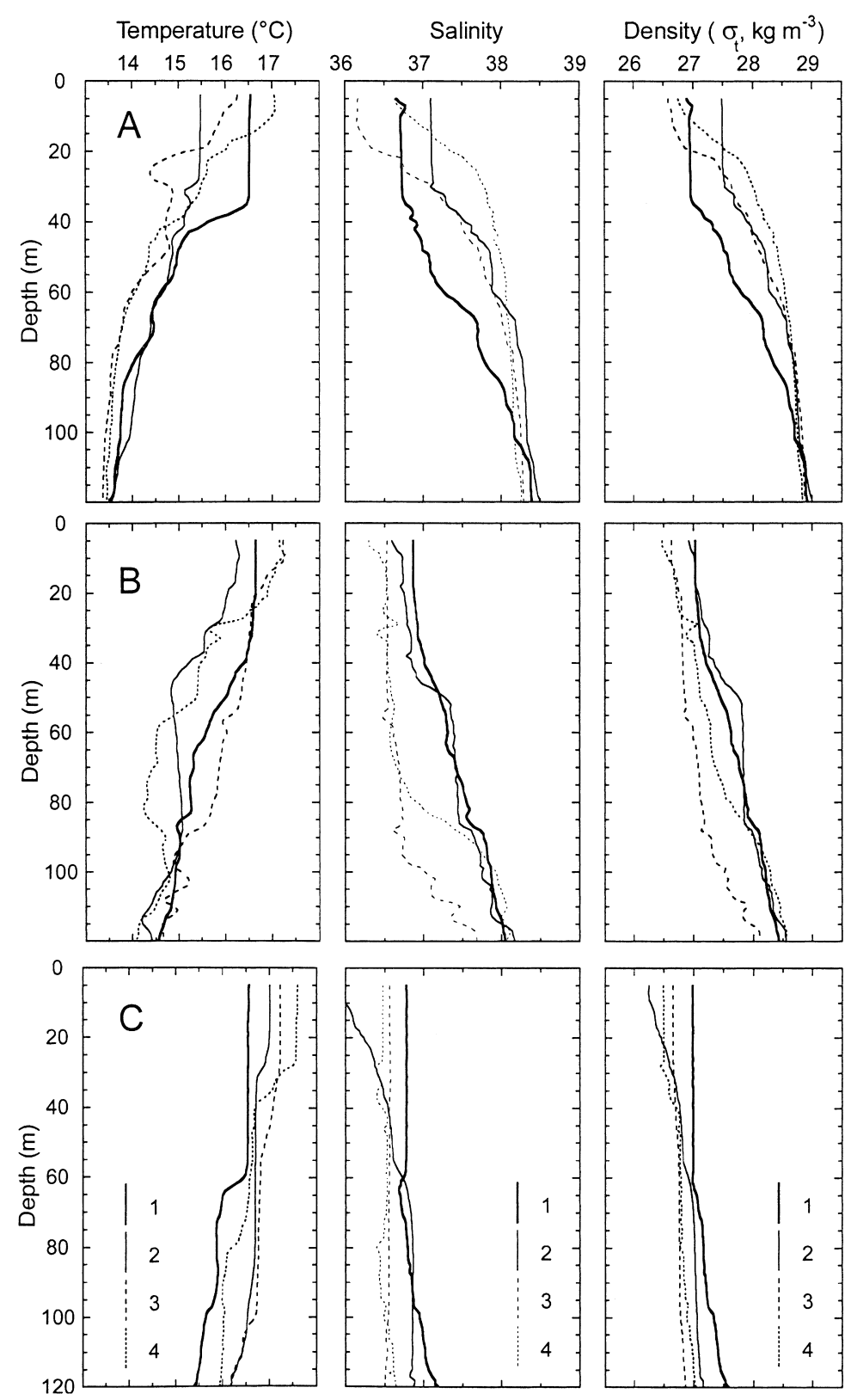

Fig. 2. Depth profiles of temperature, salinity and density for visits 1-4 to Stns A, B and C 
its to Stns A and B. No trend was observed for Stn C, in which the mixed layer was generally deeper than at the other 2 stations (Table 1). Values of $Z_{\mathrm{uml}}$ at Stns A and B showed averages of $21 \pm 15$ and $22 \pm 13 \mathrm{~m}$, respectively. A northward shallowing of the isopycnals along the transect of the 3 stations was very apparent (Fig. 1B), reflecting the position of the front formed by the jet of MAW and the coastal Mediterranean waters.

The depths of the nutriclines of nitrate $\left(Z \mathrm{NO}_{3}\right.$, first depth with concentration $\geq 1 \mu \mathrm{M})$ and phosphate $\left(Z \mathrm{PO}_{4}\right.$, first depth with concentration $\geq 0.1 \mu \mathrm{M}$ ) are shown in Table 1. During the cruise, an upwelling event produced a notable shallowing of both nutriclines at Stn A: $Z \mathrm{NO}_{3}$ and $Z \mathrm{PO}_{4}$ decreased from, respectively, 26 and $31 \mathrm{~m}$ at Stn A1 to $<5 \mathrm{~m}$ at Stn A2. At Stn A3 a marked decrease of the concentration of nitrate, phosphate and silicate was found coinciding with the depth of a conspicuous DCM (see below). Nutrient injection into the upper layers of Stn B2 was also recorded (Table 1), but with apparently no effect on the buildup of algal biomass. Nutrient changes at Stn C were much less marked and both nutriclines were always deeper than $70 \mathrm{~m}$.

\section{Chlorophyll a}

The vertical distribution of $\mathrm{chl} a$ is shown in Fig. 3. A marked increase in the chl a concentration at Stn A was observed from visits 1 through 3, as a likely consequence of the upwelling event commented above. This station presented chl a maxima well above $5 \mathrm{mg} \mathrm{m}^{-3}$ at around $40 \mathrm{~m}$ on the last 2 visits. Maximum values at

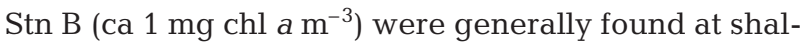
low depths $(<40 \mathrm{~m})$, although a second deep (>100 m) peak was observed at Stn B4. At Stn C, which presented less variability than the other 2 stations, con-

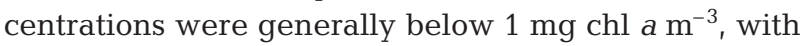
a decreasing trend between visits 1 and 4 .

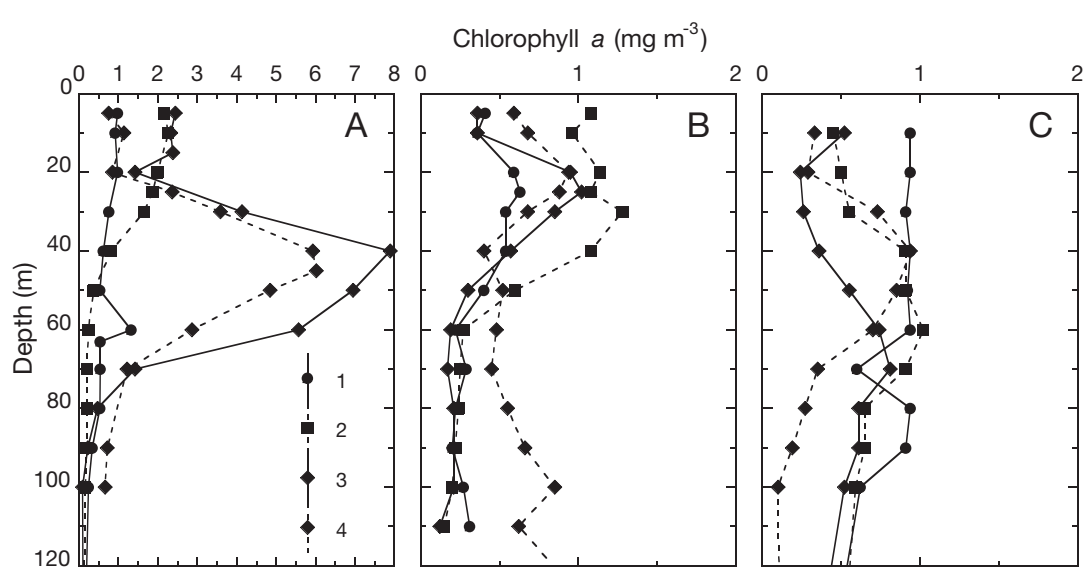

Fig. 3. Vertical distribution of total chl a for visits 1-4 to Stns A, B and C. Note the different scale for Stn A
Integrated chl a values down to $100 \mathrm{~m}$ depth (chl $a_{\text {int }}$ ) ranged from 36 to $307 \mathrm{mg} \mathrm{chl} \mathrm{a} \mathrm{m}^{-2}$. Mean values for the 3 stations were $170 \pm 117 \mathrm{SD}(\mathrm{Stn} \mathrm{A}), 49 \pm 13$

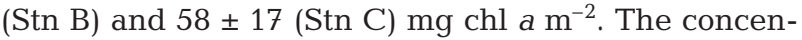
tration of chl $a$ at the surface ( $\mathrm{chl} a_{0}$ ) was significantly correlated to chl $a_{\text {int }}(\log -\log , \mathrm{r}=0.60 ; \mathrm{p}=0.023 ; \mathrm{n}=$ 14). The depth of the euphotic layer $\left(\begin{array}{lll}Z & 1 \% & E_{0}\end{array}\right)$ showed significant negative correlations with chl $a_{\text {int }}$, chl $a_{0}$ and the measured fractions of chl a for all available data, indicating a high contribution of phytoplankton biomass to the vertical light attenuation coefficients. The most remarkable temporal changes were again observed at Stn A, where chl $a_{\text {int }}$ at Stns A3 and A4 were respectively 4.8 and 3.6 times higher than the initially sampled (Stn A1) value. At this station, significant high negative correlations were found between $Z_{\mathrm{uml}}$ and chl $a_{\text {int, }}$ for total values $(\mathrm{r}=-0.98 ; \mathrm{p}=0.004 ; \mathrm{n}=5)$ and the fractions $>5 \mu \mathrm{m}$ $(\mathrm{r}=-0.99 ; \mathrm{p}=0.009 ; \mathrm{n}=4)$ and $>20 \mu \mathrm{m}(\mathrm{r}=-0.97$; $\mathrm{p}=0.026 ; \mathrm{n}=4$ ), indicating the effect of the upwelling on the buildup of algal biomass. Changes in the dominant organisms and the percentage of the different size-classes of chl a confirmed the appearance of an advected phytoplankton bloom at Stn A. Between visits 1 and 4 at Stn A, a shift in dominance from coccolithophorids and autotrophic flagellates to diatoms occurred (L. Arin pers. comm.) and whereas the percentage of $\mathrm{chl} a_{\text {int }}>20 \mu \mathrm{m}$ decreased steadily throughout the visits to Stns B and $\mathrm{C}$ to a final value of 9 and $5 \%$ of the total, respectively, such percentage increased from $32 \%$ at Stn A1 to $60 \%$ at Stn A3 (54\% at Stn A4). The depth of the nutriclines, as a proxy for nutrient supply into the upper layer (Cleveland et al. 1989), was significantly correlated with chl $a_{0}$ for all stations $\left(r=-0.59, p=0.042\right.$ for $Z N_{3} ; r=$ $-0.63, \mathrm{p}=0.028$ for $Z \mathrm{PO}_{4} ; \mathrm{n}=12$ ).

\section{Photosynthetic parameters}

Selected $P$-E curves obtained from POC data are shown in Fig. 4. Whereas $\mathrm{PO}^{14} \mathrm{C}$ and $\mathrm{TO}^{14} \mathrm{C}$ similarly increased in a typical non-linear fashion within the experimental range of irradiance, $\mathrm{DO}^{14} \mathrm{C}$ virtually did not change. To test this, average DOC was calculated at each experiment for all irradiance levels lower and greater than the corresponding saturating irradiance $\left(E_{k}\right)$. The difference between both sets of values was not significant (Wilcoxon's matched pairs test, $\mathrm{p}=0.56 ; \mathrm{n}=28$ ). Table 2 shows the mean photosynthetic parameters 


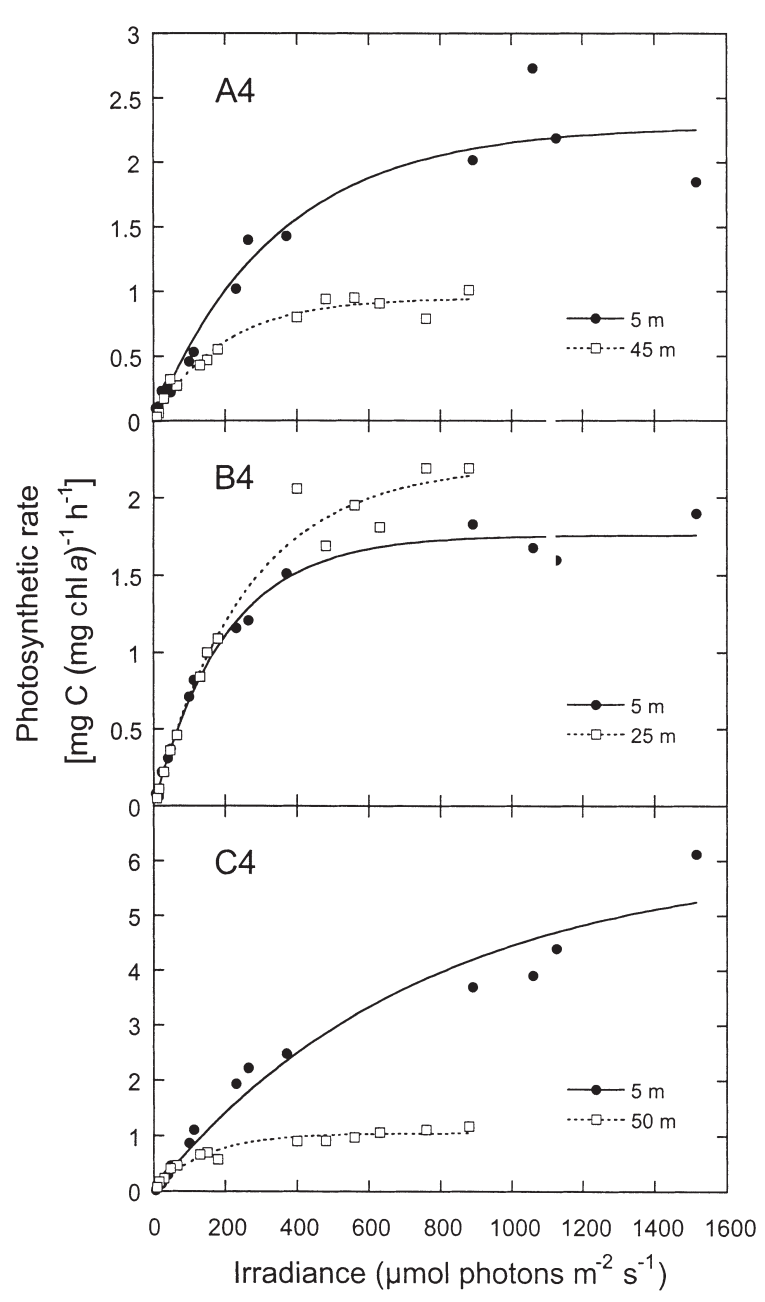

Fig. 4. Photosynthesis-irradiance plots and fitted curves for the experiments carried out at Stns A4, B4 and C4

calculated with POC data for the depth ranges less than and greater than $30 \mathrm{~m}$. Of the 34 curves obtained, 28 yielded good fits to the model with $\mathrm{r}^{2}>0.90$ and the remaining 6 had fits with $\mathrm{r}^{2}$ between 0.80 and 0.90. Both the maximum chl a-normalized photosynthetic rate $\left(P_{\mathrm{m} \text { POC }}^{\mathrm{B}}\right)$ and the maximum light utilization coefficient $(\alpha)$ ranged over 1 order of magnitude, from 0.54 to $6.05 \mathrm{mg} \mathrm{C}(\mathrm{mg} \mathrm{chl} \mathrm{a})^{-1} \mathrm{~h}^{-1}$ and from 0.0028 to $0.0168 \mathrm{mg} \mathrm{C}(\mathrm{mg} \mathrm{chl} a)^{-1} \mathrm{~h}^{-1}$ ( $\mu$ mol photons $\left.\mathrm{m}^{-2} \mathrm{~s}^{-1}\right)^{-1}$, respectively. Highest values of both parameters were found in surface waters of Stns C4 and $\mathrm{C} 4 \mathrm{~b}$. No photoinhibition was detected with the experimental irradiance range, even for the deepest samples $(80 \mathrm{~m})$, and the values of $E_{k}$ were generally above $100 \mu \mathrm{mol}$ photons $\mathrm{m}^{-2}$

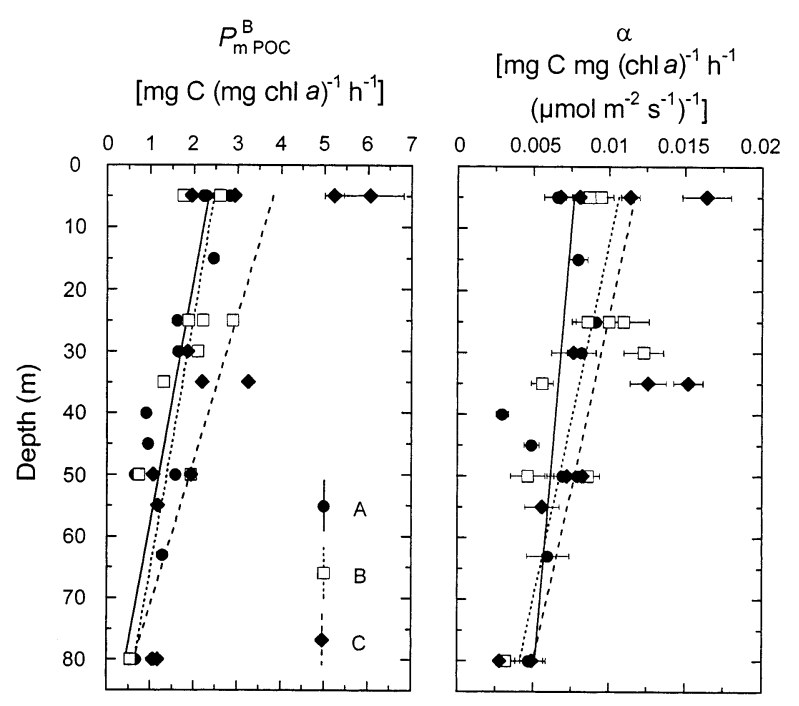

Fig. 5. Distribution of $P^{\mathrm{B}}$ POC and $\alpha$ with depth for the $P-E$ experiments. Bars are standard errors of the estimates. Lines are linear regressions for each station. Coefficients of correlation for $P_{\mathrm{m} \text { POC: }}^{\mathrm{B}} \mathrm{r}=-0.86, \mathrm{p}=0.0003(\operatorname{Stn} \mathrm{A}) ; \mathrm{r}=-0.73, \mathrm{p}=$ $0.017(\operatorname{Stn} B) ; r=-0.72, p=0.008$ (Stn C). Coefficients of correlation for $\alpha: r=-0.46, p=0.13(\operatorname{Stn} A) ; r=-0.68, p=0.031$ $(\operatorname{Stn} B) ; r=-0.60, p=0.041(\operatorname{Stn} C)$

$\mathrm{s}^{-1}$ (average $251 \pm 111 \mathrm{SD} \mu \mathrm{mol}$ photons $\mathrm{m}^{-2} \mathrm{~s}^{-1}$ ) regardless of the sampling depth. Both $P^{\mathrm{B}}{ }_{\mathrm{m} P O C}$ and $\alpha$ were significantly negatively correlated with depth at the 3 stations (Fig. 5). Despite noticeable changes in chl a concentration, especially at Stn A, surface photosynthetic parameters varied little throughout the cruise, except for Stn $\mathrm{C}$, where $P^{\mathrm{B}}$ m POC increased from values similar to those of Stns A and B [2 to $3 \mathrm{mg} \mathrm{C} \mathrm{(mg} \mathrm{chl} \mathrm{a})^{-1}$ $\mathrm{h}^{-1}$ ] to ca $6 \mathrm{mg} \mathrm{C}(\mathrm{mg} \mathrm{chl} \mathrm{a})^{-1} \mathrm{~h}^{-1}$ on the last visit. With pooled data from all experiments, $P^{\mathrm{B}}$ POC and $\alpha$ were significantly correlated (Fig. 6). The linear regression between both parameters was $P_{\mathrm{m} \text { POC }}^{\mathrm{B}}=-0.09+244 \alpha$; $\mathrm{p}<0.000001 ; \mathrm{r}^{2}=0.69 ; \mathrm{n}=33$.

The slope of the regression between $P_{\mathrm{m}}^{\mathrm{B}}$ and $\alpha$, another way of estimating the average $E_{k}$, gave a value

Table 2. Mean values \pm SD of photosynthetic parameters calculated with POC measurements in the depth ranges 0 to 30 and $>30 \mathrm{~m}$ for each station. $P^{\mathrm{B}}{ }_{\mathrm{m} \text { POC}}$ : maximum chl a-normalized photosynthetic rate $\left[\mathrm{mg} \mathrm{C}\left(\mathrm{mg} \mathrm{chl}^{-1}\right)^{-1} \mathrm{~h}^{-1}\right]$; $\alpha$ : initial slope of the $P$-E curve [mg C $\left.(\mathrm{mg} \mathrm{chl} a)^{-1} \mathrm{~h}^{-1}\left(\mu \mathrm{mol} \text { photons } \mathrm{m}^{-2} \mathrm{~s}^{-1}\right)^{-1}\right] ; E_{k}$ : light saturation parameter ( $\mu$ mol photons $\mathrm{m}^{-2} \mathrm{~s}^{-1}$ ). Chl a: concentration of total chl a $\left(\mathrm{mg} \mathrm{m}^{-3}\right)$ weighted for the depths 0 to 30 and 30 to $80 \mathrm{~m}$

\begin{tabular}{|cccccc|}
\hline Stn & $\begin{array}{c}\text { Depth } \\
(\mathrm{m})\end{array}$ & Chl $a$ & $P_{\mathrm{m} \text { POC }}^{\mathrm{B}}$ & $\alpha$ & $E_{k}$ \\
\hline $\mathrm{A}$ & $0-30$ & $1.70 \pm 0.68$ & $2.18 \pm 0.47$ & $0.0078 \pm 0.0010$ & $285 \pm 76$ \\
& $>30$ & $1.49 \pm 1.33$ & $1.00 \pm 0.36$ & $0.0056 \pm 0.0018$ & $191 \pm 72$ \\
$\mathrm{~B}$ & $0-30$ & $0.75 \pm 0.25$ & $2.24 \pm 0.43$ & $0.0100 \pm 0.0014$ & $227 \pm 53$ \\
& $>30$ & $0.39 \pm 0.25$ & $1.13 \pm 0.63$ & $0.0055 \pm 0.0023$ & $211 \pm 60$ \\
$\mathrm{C}$ & $0-30$ & $0.56 \pm 0.27$ & $3.60 \pm 1.93$ & $0.0101 \pm 0.0040$ & $372 \pm 214$ \\
& $>30$ & $0.45 \pm 0.08$ & $1.59 \pm 0.83$ & $0.0081 \pm 0.0044$ & $228 \pm 74$ \\
& & & & & \\
\hline
\end{tabular}




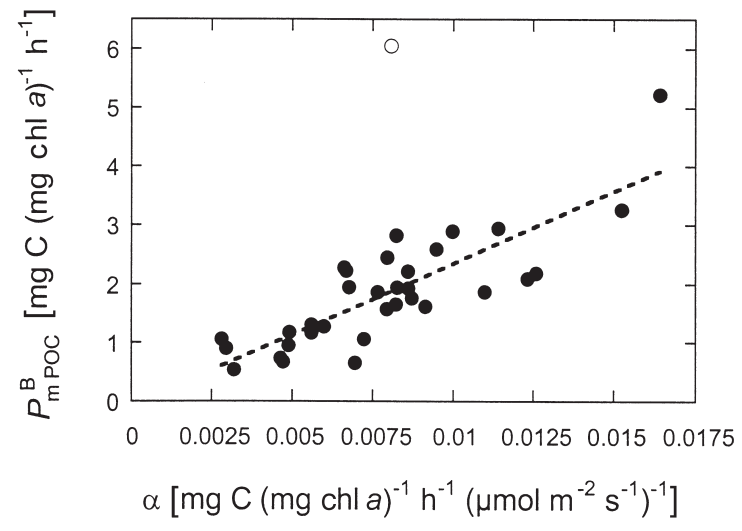

Fig. 6. Relationship between $P^{\mathrm{B}}$ POC and $\alpha$ for all experiments. Linear regression equation given in the text. The open symbol (Stn C4) was not included in the calculations

of $244 \mu \mathrm{mol}$ photons $\mathrm{m}^{-2} \mathrm{~s}^{-1}$ (cf. $251 \mu \mathrm{mol}$ photons $\mathrm{m}^{-2}$ $\mathrm{s}^{-1}$ ). Photosynthetic parameters were not correlated with the amount of chl $a$ in the different size-classes or with nutrient concentrations, except for nitrite, which was negatively correlated with $P^{\mathrm{B}}(-0.48, \mathrm{p}=0.017, \mathrm{n}$ $=24)$ and $E_{k}(-0.46, \mathrm{p}=0.026, \mathrm{n}=24)$, probably reflecting an opposite variation with depth.

Mean $P-E$ parameters calculated with TOC measurements are given in Table $3 . \mathrm{r}^{2}$ values for the fitted model were generally lower and more variable than for POC measurements. Paired $t$-tests were performed to compare $P^{\mathrm{B}}{ }_{\mathrm{m}}, \alpha$ and $E_{k}$ values obtained with TOC and POC measurements. $P_{\mathrm{m}}^{\mathrm{B}}$ values obtained with TOC $\left(P_{\mathrm{m} \text { TOC }}^{\mathrm{B}}\right)$ were significantly higher than corresponding

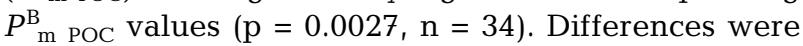
not significant for $\alpha$ values ( $\mathrm{p}=0.67, \mathrm{n}=34)$ and marginally significant for $E_{k}(\mathrm{p}=0.047, \mathrm{n}=34)$.

\section{Particulate and dissolved primary production}

Percent extracellular release (PER) values were obtained for each experimental irradiance $\left(\mathrm{PER}_{E}\right)$ by calculating DOC/(POC + DOC) from the direct measurements of both variables. As an example, Fig. 7

Table 3. Photosynthetic parameters calculated with TOC measurements (see Table 2 for details)

\begin{tabular}{|ccccc|}
\hline Stn & Depth $(\mathrm{m})$ & $P_{\mathrm{m} \text { TOC }}^{\mathrm{B}}$ & $\alpha$ & $E_{k}$ \\
\hline $\mathrm{A}$ & $0-30$ & $2.78 \pm 0.94$ & $0.0079 \pm 0.0027$ & $377 \pm 117$ \\
& $>30$ & $1.50 \pm 0.66$ & $0.0052 \pm 0.0032$ & $393 \pm 342$ \\
$\mathrm{~B}$ & $0-30$ & $2.68 \pm 0.32$ & $0.0090 \pm 0.0021$ & $319 \pm 119$ \\
& $>30$ & $1.57 \pm 1.13$ & $0.0062 \pm 0.0030$ & $255 \pm 120$ \\
$\mathrm{C}$ & $0-30$ & $3.90 \pm 1.95$ & $0.0110 \pm 0.0042$ & $362 \pm 166$ \\
& $>30$ & $1.77 \pm 0.72$ & $0.0091 \pm 0.0039$ & $210 \pm 70$ \\
& & & & \\
\hline
\end{tabular}

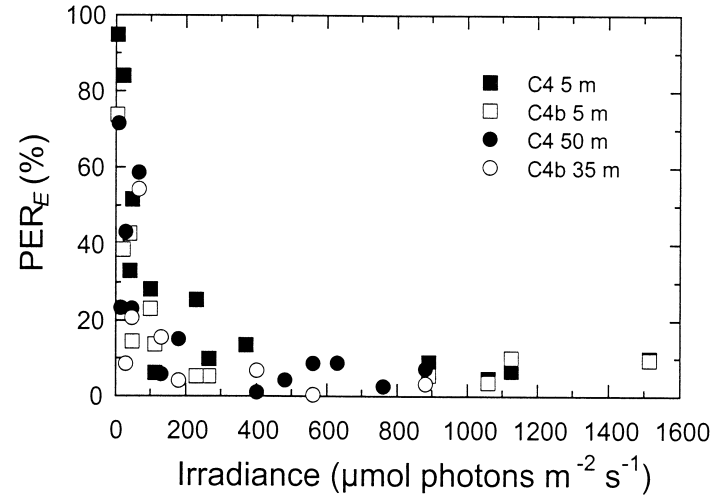

Fig. 7. Relationship between percent extracellular release $\left(\mathrm{PER}_{E}\right)$ and irradiance in the $P-E$ experiments carried out with samples from different depths at Stns C4 and C4b

shows the variation of $\mathrm{PER}_{E}$ with incubation irradiance for the $P-E$ experiments carried out at Stns $\mathrm{C} 4$ and $C 4 \mathrm{~b}$. Increased values of $\mathrm{PER}_{E}$ were obtained at low irradiances, whereas for irradiances $>200 \mu \mathrm{mol}$ photons $\mathrm{m}^{-2}$ $\mathrm{s}^{-1}, \mathrm{PER}_{E}$ was generally below $15 \%$. Although greatly variable, the trend of increasing $\mathrm{PER}_{E}$ with decreasing irradiance was still observed with all available data, both for the experiments under the surface and the deep ranges of irradiance (Fig. 8).

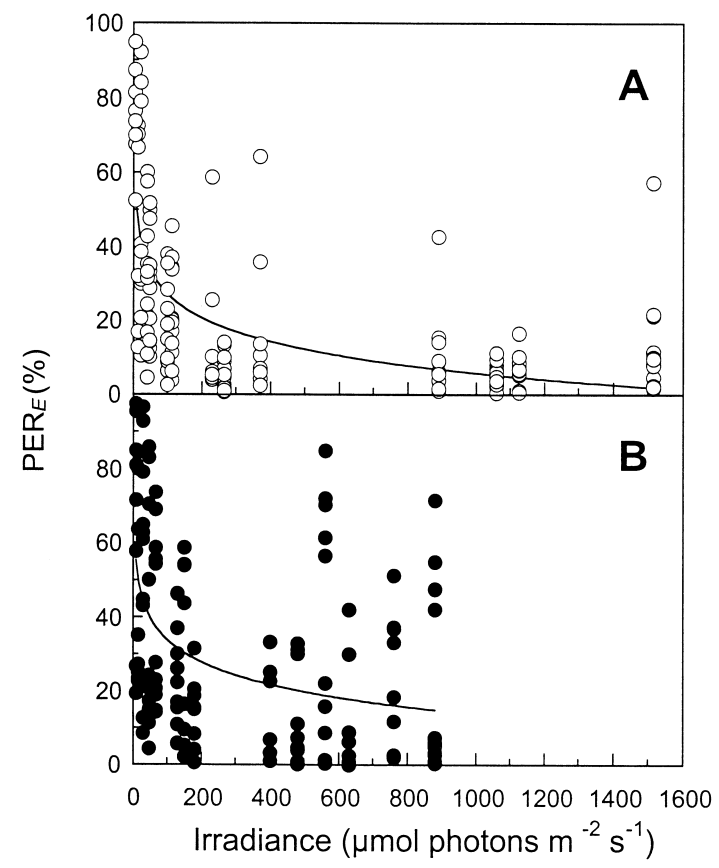

Fig. 8. Relationships between $\mathrm{PER}_{E}$ and irradiance $(E)$ for all experiments. (A) Superficial samples (experiments made under a range of 5.4 to $1515 \mu \mathrm{mol}$ photons $\mathrm{m}^{-2} \mathrm{~s}^{-1}$ ). Regression line: $\mathrm{PER}_{E}=71.6-22.1 \log E_{;} \mathrm{p}=0.000001, \mathrm{r}^{2}=0.46 ; \mathrm{n}=146$. (B) Deep samples (experiments made under a range of 8.5 to $880 \mu \mathrm{mol}$ photons $\mathrm{m}^{-2} \mathrm{~s}^{-1}$ ). Regression line: $\mathrm{PER}_{E}=74.1-20.1$ $\log E ; \mathrm{p}<0.000001, \mathrm{r}^{2}=0.22 ; \mathrm{n}=134$ 
In 23 out of the 34 experiments, the difference between $P^{\mathrm{B}}$ TOC and $P_{\mathrm{m} \text { POC }}^{\mathrm{B}}$ was positive and a lightsaturated chl a-normalized photosynthetic rate for the dissolved fraction $\left(P_{\mathrm{m} \text { DOC }}^{\mathrm{B}}\right)$ could be calculated as $P_{\mathrm{m} \mathrm{DOC}}^{\mathrm{B}}=P_{\mathrm{m} \text { TOC }}^{\mathrm{B}}-P_{\mathrm{m} \text { POC. In the remaining } 11 \text { incu- }}^{\mathrm{B}}$ bations, $P_{\mathrm{m}}^{\mathrm{B}}$ TOC values were slightly lower than the corresponding $P_{\mathrm{m}}^{\mathrm{B}}$ POC ones. PER considering these $P_{\mathrm{m} \text { DOC }}^{\mathrm{B}}$ values $\left(\mathrm{PER}_{\mathrm{m}}=P_{\mathrm{m} \text { DOC }}^{\mathrm{B}} P_{\mathrm{m}}^{\mathrm{B}}\right.$ TOC $)$ tended to increase with depth. A linear regression with all data gave $\mathrm{PER}_{\mathrm{m}}=15+0.34 Z_{;} \mathrm{p}=0.041 ; \mathrm{r}^{2}=0.18 ; \mathrm{n}=23$.

\section{Integrated primary production. Relationships with chl a concentration}

$\mathrm{PP}_{\text {int }}$ varied noticeably during the cruise at the 3 stations and was also dependent on the procedure used for integration (see Table 4), although to a relatively small extent, as differences were not significant ( $t$-test for dependent samples, $\mathrm{PP}_{\text {int }} \mathrm{POC}$ no. 1 and $\mathrm{PP}_{\text {int } \mathrm{POC}}$ no. $2, \mathrm{p}=0.14 ; \mathrm{PP}_{\text {int TOC }}$ no. 1 and $\mathrm{PP}_{\text {int TOC }}$ no.2, $\mathrm{p}=$ $0.25 ; \mathrm{n}=14)$. Therefore, only the linear interpolation approach values (procedure no. 2) will be used hereafter. $\mathrm{PP}_{\text {int }} \mathrm{POC}$ ranged from 42 to $956 \mathrm{mg} \mathrm{C} \mathrm{m} \mathrm{m}^{-2} \mathrm{~d}^{-1}$ and $\mathrm{PP}_{\text {int TOC }}$ ranged from 47 to $1634 \mathrm{mg} \mathrm{C} \mathrm{m}^{-2} \mathrm{~d}^{-1}$. As the effect of phytoplanktonic respiration of labelled carbon in short incubations is low (Williams et al. 1996) and the calculation did not consider phytoplankton respiration during the night, these values would be closer to gross than to net primary production rates (Williams 1993). In general, $\mathrm{PP}_{\text {int }}$ decreased following the coastal-offshore gradient. Mean $( \pm \mathrm{SE})$

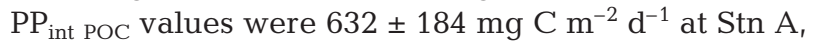
$388 \pm 123 \mathrm{mg} \mathrm{C} \mathrm{m}{ }^{-2} \mathrm{~d}^{-1}$ at Stn B and $330 \pm 149 \mathrm{mg} \mathrm{C}$ $\mathrm{m}^{-2} \mathrm{~d}^{-1}$ at Stn C. Except for the first visit, $\mathrm{PP}_{\text {int }}$ was always highest at Stn A. Due to upwelling and the subsequent nutrient consumption and biomass increase found at this station, $\mathrm{PP}_{\text {int }}$ increased more than 2-fold from Stns A1 to A2 and A3 (Table 4). During the fourth visit, Stns A and C were sampled twice. From morning to afternoon (ca 8 and $6 \mathrm{~h}$ difference, respectively), estimated $\mathrm{PP}_{\text {int } \mathrm{POC}}$ increased 1.7-fold at Stn A and 3.0-fold at Stn C. This increase also held true for $\mathrm{PP}_{\text {int TOC, }}$ with a 1.9fold increase at Stn A and 3.0-fold at Stn C.

Particulate and total $\mathrm{PP}_{\text {int }}$ were well correlated with chl $a_{0}$, but not with chl $a_{\text {int }}(\mathrm{p}>0.12)$. The corresponding linear regressions with $\mathrm{chl} a_{0}$ (Fig. 9) were: $\log \mathrm{PP}_{\text {int } \mathrm{POC}}=2.63+1.11 \log \mathrm{chl}$ $a_{0} ; r^{2}=0.55 ; p=0.0024 ; n=14 . \log P_{\text {int }}$ тоC $=2.64+1.22 \log \operatorname{chl~} a_{0} ; r^{2}=0.63 ;$ $\mathrm{p}=0.0007 ; \mathrm{n}=14$.

$\mathrm{PP}_{\text {int }} \mathrm{POC}$ was positively correlated to total incident irradiance $(\mathrm{r}=0.65, \mathrm{p}=$ $0.011, \mathrm{n}=14$ ) and negatively correlated with the depth of the euphotic layer, $Z 1 \% E_{0}(\mathrm{r}=-0.61, \mathrm{p}=0.022, \mathrm{n}=$ 14). This latter negative relationship was expected from the fact that chl absorbs a higher percentage of light, relative to the water, when contained in a narrow layer within a shallow euphotic zone, than when found at deeper levels. As can be seen in Fig. 10, particulate primary production at the 3 stations was mainly confined to the upper layers of the water column. Values $>10 \mathrm{mg} \mathrm{C} \mathrm{m}^{-3} \mathrm{~d}^{-1}$ were usually only found at depths shallower than $20 \mathrm{~m}$. 


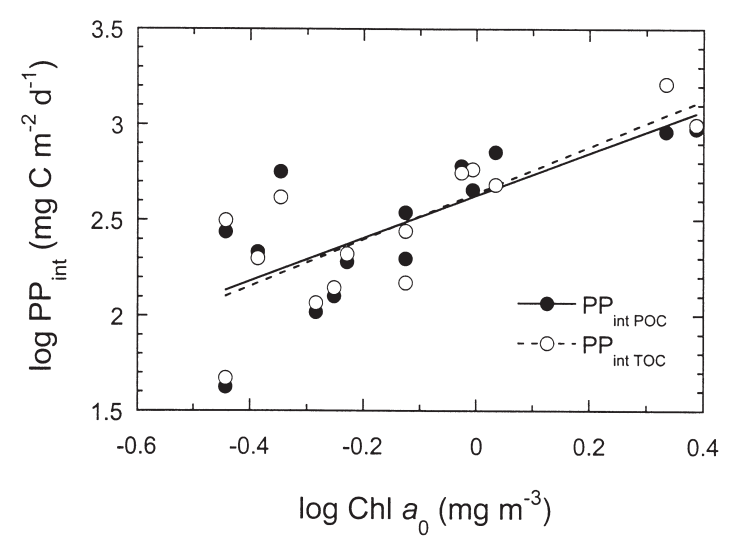

Fig. 9. Relationship between integrated primary production $\left(\mathrm{PP}_{\text {int }}\right)$ and surface $\mathrm{chl}$ a $\left(\mathrm{chl} \mathrm{a}_{0}\right)$ for all data. Regression equations are given in the text

An integrated value of PER for the 0 to 100 depth range $\left(\mathrm{PER}_{\text {int }}\right)$ was calculated where possible by using the difference between $\mathrm{PP}_{\text {int TOC }}$ and $\mathrm{PP}_{\text {int POC }}$ as an estimate of the integrated dissolved primary production. These values are shown in Table 4 and were on average higher $(24 \%)$ at Stn A, although highly variable on different days. At the other 2 stations, average PER $\mathrm{P}_{\text {int }}$ were the same $(11 \%)$ and virtually constant.

\section{DISCUSSION}

Elevated concentrations of chl a have been previously reported for the Western Alboran Sea (Jiménez et al. 1987, Minas et al. 1991, Rodríguez et al. 1994, 1998), but direct measurements of primary productivity for this sub-basin are lacking. Our results show that a noticeable variability in chl a distribution and primary production rates estimated from $P$-E relationships occurred at a time scale of days in the northern part of the Western Alboran Gyre. The main change observed was a marked increase in phytoplankton biomass and production parallel to nutrient consumption at subsurface levels of Stn A, located in the frontal region between the MAW jet and the Mediterranean waters. At the same time, a shift in the dominant sizeclasses of chl $a_{\text {, from }} 68 \%$ of chl $a_{\text {int }}$ smaller than $20 \mu \mathrm{m}$ to $54 \%$ greater than that size, reflected a marked increase in diatom abundance (L. Arin et al. unpubl.). These changes were too fast to have originated in situ and can be explained as the result of advection of water masses being affected by an upwelling event of increasing intensity. According to the hydrodynamical regime in the study area, and the location of Stn A in the northern part of the Western Alboran Gyre, the advected waters were probably coming from the west (Gómez et al. 2000).
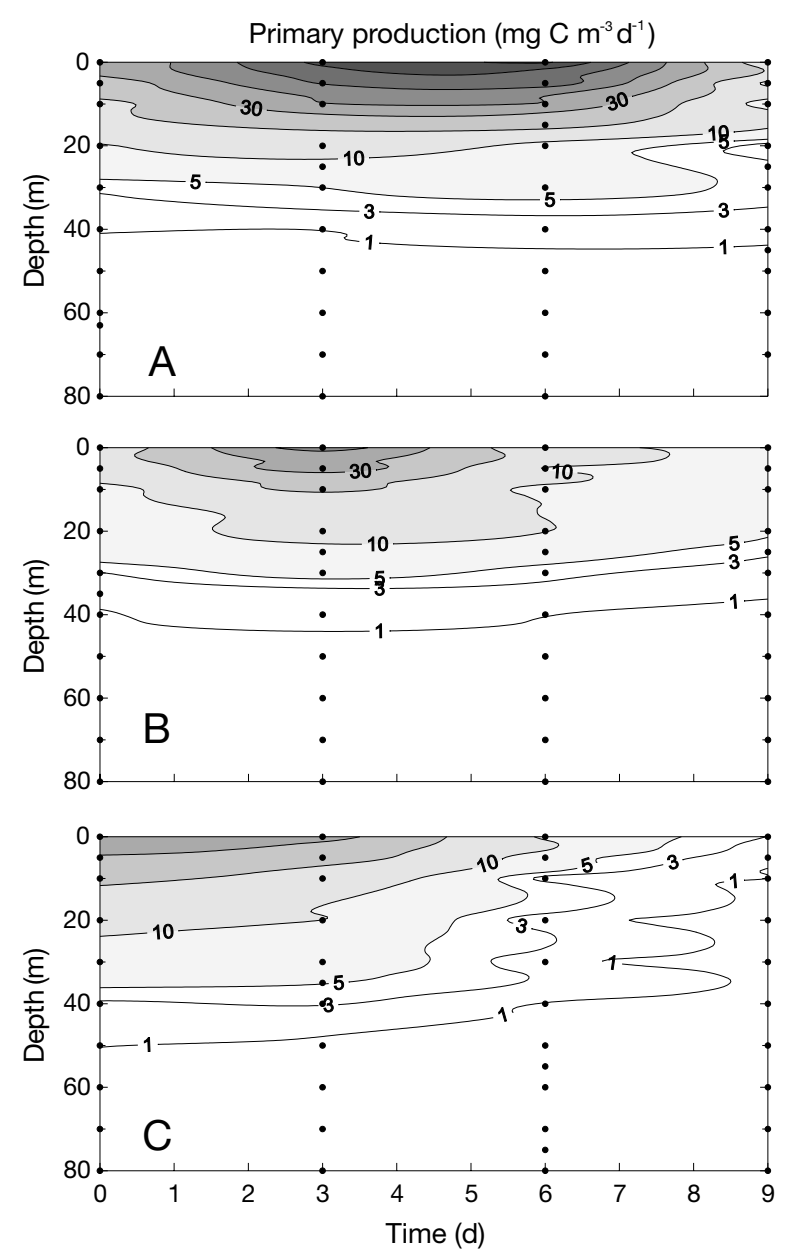

Fig. 10. Temporal variation of the rate of particulate primary production at the 3 sampled stations

\section{Photosynthetic parameters}

The range of variation of the maximum photosynthetic rates, with averages of $2.0\left(P_{\mathrm{m} \mathrm{POC}}^{\mathrm{B}}\right)$ and $2.4 \mathrm{mg}$ C $(\mathrm{mg} \text { chl a })^{-1} \mathrm{~h}^{-1}\left(P_{\mathrm{m}}^{\mathrm{B}} \quad\right.$ TOC$)$, was comparable, although shifted to slightly higher values, to that of the unique $P-E$ measurements previously reported for the Alboran Sea, at the Almería-Oran Front (Videau et al. 1994). Both $P_{\mathrm{m} \text { POC }}^{\mathrm{B}}$ and $P_{\mathrm{m}}^{\mathrm{B}}$ TOC varied by a factor of 11 (CV $60 \%)$, which was notably high for a small area and short time scale when compared to the variability found during ocean-scale surveys (a factor of 4 in Hood 1995, 9 and 18 in Kyewalyanga et al. 1998, but 30 in Marañón \& Holligan 1999) or with a temporally more extended data set (a factor of 4 , over a period of 70 d in Côté \& Platt 1983). The values of the initial slope or maximum light utilization coefficient $(\alpha)$ were very low [mostly $<0.01 \mathrm{mg} \mathrm{C}$ (mg chl $a)^{-1} \mathrm{~h}^{-1}$ ( $\mu \mathrm{mol}$ photons $\left.\mathrm{m}^{-2} \mathrm{~s}^{-1}\right)^{-1}$, Tables 2 \& 3], falling in the lower part of recently reported ranges 
covering much larger distances in the Atlantic (Hood 1995, Kyewalyanga et al. 1998, Marañón \& Holligan 1999), and varied by a factor of 6 . The comparatively lower variability of $\alpha$ compared with $P^{\mathrm{B}}$ may have been expected (Geider 1993), as this parameter appears to be a function of basic photochemical reactions (Côté \& Platt 1983). The marked increase in $P_{\mathrm{m}}^{\mathrm{B}}$ and $\alpha$ at the surface of Stn $\mathrm{C}$ from the first to the last visit (see Fig. 5) suggests that either a shift in the composition of the superficial phytoplankton assemblages or a change in their photophysiological status had occurred. The same water mass was sampled at Stns $\mathrm{C} 4$ and $\mathrm{C} 4 \mathrm{~b}$ as judged from the distribution of physical variables, so the 2 -fold increase in $\alpha$ from morning to afternoon $\left[0.008\right.$ and $0.016 \mathrm{mg} \mathrm{C} \mathrm{mg} \mathrm{chl} \mathrm{a}^{-1} \mathrm{~h}^{-1}$ ( $\mu \mathrm{mol}$ photons $\left.\mathrm{m}^{-2} \mathrm{~s}^{-1}\right)^{-1}$, Fig. 6] could perhaps reflect a process of photoacclimation of the phytoplankton taking place at that time. On the contrary, no trend was observed in the photosynthetic parameters of Stn A during the period of study as a result of the nutrient injection event, even though a change in the hydrological conditions and the dominant phytoplankton assemblages had effectively taken place.

According to our results, the most important source of variation of the $P-E$ parameters in the area was depth, presumably as a result of covariation of depth with other variables such as irradiance. As a consequence of both the overall low values of $\alpha$ and the high covariation of $P_{\mathrm{m} \text { POC }}^{\mathrm{B}}$ and $\alpha$ (Fig. 4), the $E_{k}$ values were rather high (mean of either 244 or $251 \mu \mathrm{mol}$ photons $\mathrm{m}^{-2} \mathrm{~s}^{-1}$, depending on the method of estimation), suggesting that phytoplankton assemblages were acclimated to high irradiance levels in the whole area. The absence of photoinhibition indicates that even the deeper cells could stand relatively high light intensities, implying that they had not been exposed to constantly low irradiances in their recent light history (Platt et al. 1980, Harding et al. 1987). This was the expected result if vertical mixing was sufficiently strong to bring these cells to shallow depths in a period short enough to prevent shade acclimation (Lewis et al. 1984, Cullen \& Lewis 1988). In contrast, decreasing $P_{\mathrm{m} \text { POC }}^{\mathrm{B}}$ with depth is commonly interpreted as a result of shade acclimation (Falkowski 1981). Decreasing $P_{\mathrm{m} \text { POC }}^{\mathrm{B}}$ is frequently associated with increasing $\alpha$ (e.g. Dower \& Lucas 1993, Basterretxea \& Arístegui 2000, Morán et al. 2001), whereas both parameters decreased similarly with depth in our experiments (Fig. 5). Decreasing $\alpha$ with depth could be due to the packaging of pigments inside the chloroplasts (Sakshaug et al. 1997) or might reflect a parallel decrease in the C:chl a ratio (Geider et al. 1996, Taylor et al. 1997, Marañón \& Holligan 1999), thus yielding no significant differences between surface and deep photosynthetic parameters if they were normalized to carbon instead of to $\mathrm{chl} a$. In that case, however, it would be difficult to explain why the vertical mixing would be strong enough to avoid photoacclimation of $P^{\mathrm{B}}$ and $\alpha$ values, but not to prevent differences in the $\mathrm{C}: \mathrm{chl} a$ ratio. An alternative explanation for the observed pattern could be related to temporal variability of hydrological features. Differential rates of change of physiological components in response to changes in irradiance could be expected (Lewis et al. 1984) if a different vertical light regime was being established due to a change in the physical conditions of the water column (i.e. due to increased stratification). Geider (1993) showed for instance that $P^{\mathrm{B}}$ and $\alpha$ respond differently, on a time basis, to changing irradiances. The slightly higher covariance with depth of $P_{\mathrm{m} \text { POC }}^{\mathrm{B}}(\mathrm{r}=0.66 ; \mathrm{p}<0.001)$ compared with that of $\alpha(\mathrm{r}=0.53 ; \mathrm{p}=0.001)$ or $E_{k}(\mathrm{r}=0.41 ; \mathrm{p}=$ 0.017 ) could perhaps be reflecting differential rates of response of the photosynthetic parameters considered.

\section{Particulate and dissolved primary production}

A clear relationship between irradiance and PER was identified, with consistently higher $\mathrm{PER}_{E}$ at lower irradiances for the whole data set (Figs. $7 \&$ 8). The high $\mathrm{PER}_{E}$ values at low irradiances were not due to an absolute increase in DOC release rates, but to a sharp decrease in POC production with decreasing irradiance. These results suggest that a more or less constant amount of photosynthesized organic carbon was being lost from the algae independently of irradiance (within the experimental range used). PER enhancement under low irradiances is in agreement with previous reports obtained with more reduced data sets (Berman \& Holm-Hansen 1974, Mague et al. 1980, Zlotnik \& Dubinsky 1989, but see Verity 1981 for an exception). Despite considerable scatter, our $\mathrm{PER}_{E}$ values (Fig. 8) were considerably higher than those found by Zlotnik \& Dubinsky (1989), who reported PERs <15\% under almost all experimental irradiances with 3 algal cultures. At each experiment, we subtracted dark bottle values from those of the light bottles. Therefore, we do not think that these higher percentages were due to dark fixation of ${ }^{14} \mathrm{CO}_{2}$ as suggested by Watanabe (1980) and Fogg (1983). If the PER-irradiance relationship found here with natural assemblages happens to be general, incubations under suboptimal irradiance levels (i.e. lower than the corresponding $E_{k}$ values) could result in PERs well above the commonly accepted values of $<20 \%$ (Baines \& Pace 1991, Hansell \& Carlson 1998).

Zlotnik \& Dubinsky (1989) also observed an increase in PER with high irradiances and it has been shown that one consequence of high irradiances, besides photoinhibition and lowering $P^{\mathrm{B}}$ values in the $P$-E relation- 
ships, is an enhanced release into the environment of organic compounds such as glycolate (Leboulanger et al. 1997), as an alternative mechanism to photorespiration (Verity 1981, Wood \& Van Valen 1990). In our case, high $\mathrm{PER}_{E}$ with high irradiances was observed at only some of the deep water experiments (Fig. 8B). This lack of generality may be partially explained by the absence of photoinhibition and the fact that, despite a trend of lower $E_{k}$ values with depth, they were generally high in our samples.

The simultaneous measurement in the $P-E$ experiments of TOC, POC and DOC production allowed a comparison of the differences in the calculated photosynthetic parameters for the total primary production and its particulate and dissolved fractions. With all data, $P_{\mathrm{m} \text { TOC }}^{\mathrm{B}}$ values were on average $19 \%$ higher than

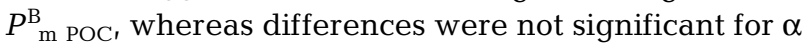
and only marginally significant for $E_{k}$. As emphasized in Sakshaug et al. (1997), all photosynthesized organic carbon is part of the primary production so that, ideally, both the particulate and the dissolved fractions should be measured, although this is seldom attempted. We tentatively estimated a potential light-saturated chl a-normalized DOC production rate $\left(P_{\mathrm{m} \text { DOC }}^{\mathrm{B}}\right)$ as the difference between fitted $P^{\mathrm{B}}$ TOC and $P^{\mathrm{B}}{ }_{\mathrm{m} \text { POC }}$ values. The relative contribution of this $P^{\mathrm{B}}$ DOC to total primary production rate $\left(\mathrm{PER}_{\mathrm{m}}\right)$ showed an increasing trend with depth when data from the 3 stations were pooled. Higher PER at depth was first reported by Thomas (1971) and Berman \& Holm-Hansen (1974), who attributed it to the presence of senescent or lightlimited cells. In our case, phytoplankton from below the upper mixed layer was effectively light-limited, i.e. experienced irradiances which were lower than their respective $E_{k}$ values. Thus, the covariance of $\mathrm{PER}_{\mathrm{m}}$ and depth could be related to the stronger effect of light limitation on POC than on DOC production as argued above.

\section{Integrated primary production}

Although differences among procedures in the estimates of $\mathrm{PP}_{\text {int }}$ were not very marked (Table 4 ), we regard the results of procedure no. 2, using interpolation of photosynthetic parameters at each depth, as more appropriate than just taking 2 sets of constant values changed at a given depth of the water column. Apart from the observation that $Z_{\text {uml }}$ was shallower than the depth of the most superficial sample at Stns C2, A3 and B3 (Table 1), the fact that P-E parameters also varied with depth within the upper mixed layer, argued against the use of the uppermost values throughout all the upper mixed layer (Dower \& Lucas 1993).
Average $\mathrm{PP}_{\text {int }}$ in this study was comparable to the data reported for frontal areas of the Alboran Sea or neighbouring Mediterranean regions (Sournia 1973, Estrada 1981, Lohrenz et al. 1988a,b, Estrada et al. 1993, Videau et al. 1994, Morán et al. 2001), but it showed a very high variability for both total and particulate values (Table 4 ) on a scale of $2 \mathrm{wk}$. The range of variation of $\mathrm{PP}_{\text {int }}$ across the Western Alboran Gyre (ca 23 for $\mathrm{PP}_{\text {int }} \mathrm{POC}$ and ca 35 for $\mathrm{PP}_{\text {int }}$ TOC) was high when compared to other parts of the Mediterranean on broader spatial and temporal scales (e.g. Sournia 1973, Lohrenz et al. 1988a,b, Estrada et al. 1993). Part of this variability was obviously due to changes in daily irradiance, but even using the average daily value obtained during the cruise, $\mathrm{PP}_{\text {int }}$ still varied by a factor of ca 6 (POC) and ca 9 (TOC). This high variability agrees with the conclusions of Côté \& Platt (1983) concerning the difficulties of predicting short-term variations in primary productivity. In spite of this variability, an expected gradient of decreasing $\mathrm{PP}_{\text {int }}$ when moving away from the coastal upwelling zone towards the center of the gyre could be identified.

Our results stress the marked effect that variations in the light profile may have in the estimation of $\mathrm{PP}_{\text {int }}$. At Stns A and C, considerable discrepancies in the estimated $\mathrm{PP}_{\text {int }}$ were obtained by sampling in the morning (Stns A4, C4) or in the afternoon (Stns A4b, C4b), with afternoon values being ca 70 and $200 \%$ higher, respectively (Table 4$)$. Changes in the chl $a_{\text {int }}$ values $(15 \%$ increase at Stn A and the same value at Stn C) or the $P$ $E$ parameters (practically the same except for $\alpha$ at Stn C) did not account for all that difference. Nevertheless, a 15 to $20 \mathrm{~m}$ shallowing of the peak of chl $a$ at both stations (Fig. 11), perhaps caused by an internal wave, increased available PAR at the depth of maximum biomass from $0.4 \%$ of the surface value to $8 \%$ at $\operatorname{Stn} A$, and from 6 to $21 \%$ at Stn C, hence leading to higher in situ estimates of primary production. Thus, short-term changes in available light for phytoplankton due to physical forcing would appear as a critical factor, neglected by logistic reasons in the conventional methods of calculating integrated rates of primary production. Although incident irradiance and vertical variability of phytoplankton biomass appear to play a relatively minor role in large data sets (Behrenfeld \& Falkowski 1997b), underwater light distribution should be carefully considered when computing primary production estimates in locations showing subsurface chlorophyll maxima. Another source of variability, not considered here, is the effect of the vertical changes in the spectral composition of light (Platt \& Sathyendranath 1988).

Although an overall significant relationship existed between surface and integrated values of chl a for all stations, $\mathrm{PP}_{\text {int }}$ showed no significant correlation with in- 


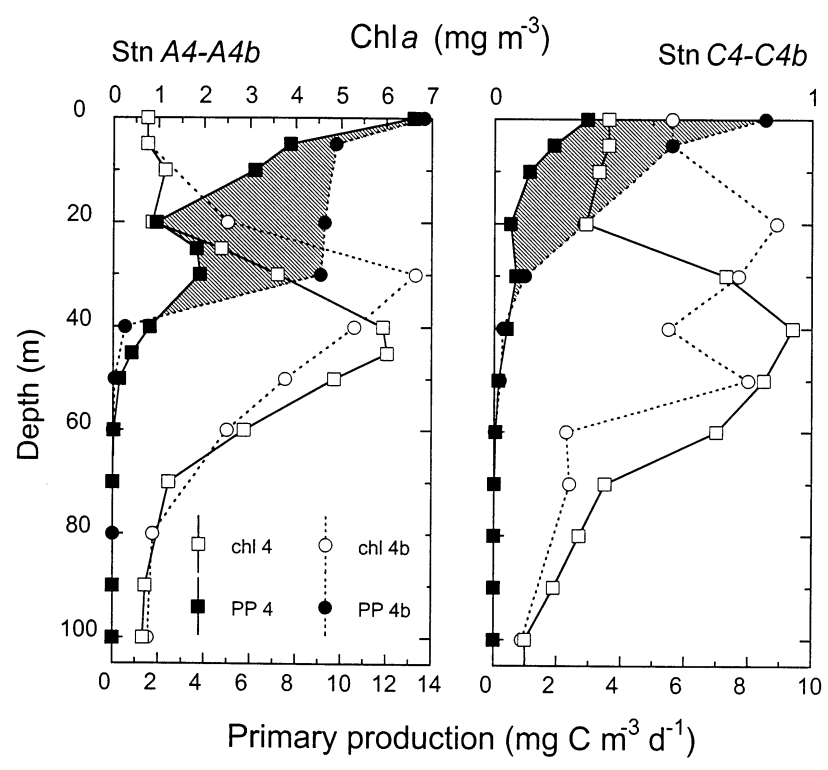

Fig. 11. Distribution of chl a and particulate primary production rates for the morning and afternoon samplings at Stns A4 and $\mathrm{C} 4$. Note the different scales. The shaded area represents the increase in estimated primary production from morning to afternoon

tegrated chl $a$. This can be explained by severe light limitation and low contribution to integrated primary production of the phytoplankton cells found at subsurface depths, which contained an important proportion of the total chl $a$ in the water column. On the contrary, $\mathrm{PP}_{\text {int TOC }}$ and $\mathrm{PP}_{\text {int }} \mathrm{POC}$ were significantly correlated to chl $a$ at $5 \mathrm{~m}$ (Fig. 9), due to the high contribution to total primary production of surface or near-surface phytoplankton cells (Fig. 10). This finding is relevant for the estimation of regional primary production based on remote sensing, especially if it proves to hold true for all periods of the year. In some cases, the development of appropriate algorithms relating near-surface colour from satellite images (SeaWiFs, and formerly CZCS) and primary productivity has been based on good knowledge of the chl a distribution with depth (Longhurst et al. 1995, Sathyendranath et al. 1995). The lack of coupling between integrated chl $a$ and primary production suggests that, in our study area, it would be more cost-effective to put more effort into determining the variability of surface chl a distributions.

Water column integrated PER values $\left(\mathrm{PER}_{\text {int }}\right.$, Table 4$)$ were lower at Stn A3 (4\%) than at Stns B3 or C3 (13 and $11 \%$, respectively), which were outside of the influence of the phytoplankton bloom found at Stn A. However, the highest PER value (44\%) was measured at Stn A2, which also presented the highest primary production. These contrasting results could be reflecting shifts in the composition and successional stage of the phytoplankton community. An alternative expla- nation for the higher PER found at this station would be, as observed by Fernández et al. (1994), a stronger dependence of bacterioplankton on phytoplanktonproduced DOC at the less productive stations, which would result in artificially low PER because of bacterial consumption in the incubation bottles. As discussed above, the measurement of net $\mathrm{DO}^{14} \mathrm{C}$ concentration in the water at the end of the incubation period does not give any hint on its possible uptake by heterotrophic bacteria.

The appreciable variability in the $P$ - $E$ relationships found in a small area of the Alboran Sea, a likely consequence of a complex interaction of physical, chemical and biological factors in a highly hydrodynamical region, emphasizes the necessity of a spatially and temporally more detailed assessment of phytoplankton photophysiology (Platt et al. 1991, Behrenfeld \& Falkowski 1997a, Sakshaug et al. 1997) to improve global ocean productivity models. The regular measurement of dissolved primary production in $P-E$ experiments and the subsequent inclusion of the relevant parameters in productivity models would improve our understanding of the dynamics of marine DOC, a pool of crucial importance in the carbon cycle considered from a biogeochemical perspective.

Acknowledgements. We thank the people on board the RV 'Hespérides' for their help during the cruise. Mikel Latasa and Belén Martín-Míguez provided helpful comments on the manuscript. X.A.G.M. acknowledges the receipt of a Formación de Personal Investigador predoctoral fellowship from the Spanish Ministry of Education and Culture. This research was supported by grant MAS3-CT96-0051.

\section{LITERATURE CITED}

Amon RMW, Benner R (1994) Rapid cycling of high-molecular-weight dissolved organic matter in the ocean. Nature 369:549-552

Baines SB, Pace ML (1991) The production of dissolved organic matter by phytoplankton and its importance to bacteria: patterns across marine and freshwater systems. Limnol Oceanogr 36:1078-1090

Basterretxea G, Arístegui J (2000) Mesoscale variability in phytoplankton biomass distribution and photosynthetic parameters in the Canary-NW African coastal transition zone. Mar Ecol Prog Ser 197:27-40

Behrenfeld MJ, Falkowski PG (1997a) Photosynthetic rates derived from satellite-based chlorophyll concentration. Limnol Oceanogr 42:1-20

Behrenfeld MJ, Falkowski PG (1997b) A consumer's guide to phytoplankton primary productivity models. Limnol Oceanogr 42:1479-1491

Berman T, Holm-Hansen O (1974) Release of photoassimilated carbon as dissolved organic matter by marine phytoplankton. Mar Biol 28:305-310

Biddanda B, Benner R (1997) Carbon, nitogen, and carbohydrate fluxes during the production of particulate and dissolved organic matter by marine phytoplankton. Limnol Oceanogr 42:506-518 
Cleveland JS, Perry MJ, Kiefer DA, Talbot MC (1989) Maximal quantum yield of photosynthesis in the northwestern Sargasso Sea. J Mar Syst 47:869-886

Coste B, Le Corre P, Minas HJ (1988) Re-evaluation of the nutrient exchanges in the Strait of Gibraltar. Deep-Sea Res 35:767-775

Côté B, Platt T (1983) Day-to-day variations in the springsummer photosynthetic parameters of coastal marine phytoplankton. Limnol Oceanogr 28:320-344

Coveney MF (1982) Bacterial uptake of photosynthetic carbon from freshwater phytoplankton. Oikos 38:8-20

Cullen JJ, Lewis MR (1988) The kinetics of photoadaptation in the context of vertical mixing. J Plankton Res 10: 1039-1063

Dower KM, Lucas MI (1993) Photosynthesis-irradiance relationships and production associated with a warm-core ring shed from the Agulhas Retroflection south of Africa. Mar Ecol Prog Ser 95:141-154

Estrada M (1981) Biomasa fitoplanctónica y producción primaria en el Mediterráneo Occidental, a principios de otoño. Invest Pesq 45:211-230

Estrada M, Marrasé C, Latasa M, Berdalet E, Delgado M, Riera T (1993) Variability of deep chlorophyll maximum characteristics in the Northwestern Mediterranean. Mar Ecol Prog Ser 92:289-300

Falkowski PG (1981) Light-shade adaptation and assimilation numbers. J Plankton Res 3:203-216

Fernández M, Bianchi M, Van Wambeke F (1994) Bacterial biomass, heterotrophic production and utilization of dissolved organic matter photosynthetically produced in the Almeria-Oran front. J Mar Syst 5:313-325

Fogg GE (1983) The ecological significance of extracellular products of phytoplankton photosynthesis. Bot Mar 26: $3-14$

Geider RJ (1993) Quantitative phytoplankton physiology: implications for primary production and phytoplankton growth. ICES Mar Sci Symp 197:52-62

Geider RJ, MacIntyre HL, Kana TM (1996) A dynamic model of photoadaptation in phytoplankton. Limnol Oceanogr 41:1-15

Gómez F, Echevarría F, García CM, Prieto L, Ruiz J, Reul A Jiménez-Gómez F, Varela M (2000) Microplankton distribution in the Strait of Gibraltar: coupling between organisms and hydrodynamic structures. J Plankton Res 22: 603-617

Hansell DA, Carlson CA (1998) Net community production of dissolved organic carbon. Global Biogeochem Cycles 12: 443-453

Harding LW Jr, Fisher TR Jr, Tyler MA (1987) Adaptive responses of photosynthesis in phytoplankton: specificity to time-scale of change in light. Biol Oceanogr 4:403-437

Heburn GW, La Violette PE (1990) Variations in the structure of the anticyclonic gyres found in the Alboran Sea. J Geophys Res 95:1599-1613

Hood RR (1995) Light response of phytoplankton in the South Atlantic Ocean: interpretation of observations and application to remote sensing. J Geophys Res 100:10927-10942

Jiménez F, Rodríguez J, Bautista B, Rodríguez V (1987) Relations between chlorophyll, phytoplankton cell abundance and biovolume during a winter bloom in Mediterranean coastal waters. J Exp Mar Biol Ecol 105:161-173

Kyewalyanga MN, Platt T, Sathyendranath S, Lutz VA, Stuart V (1998) Seasonal variations in physiological parameters of phytoplankton across the North Atlantic. J Plankton Res 20:17-42

Lancelot C (1979) Gross excretion rates of natural marine phytoplankton and heterotrophic uptake of excreted products in the southern North Sea, as determined by short-term kinetics. Mar Ecol Prog Ser 1:179-186

Leboulanger C, Oriol L, Jupin H, Descolas-Gros C (1997) Diel variability of glycolate in the eastern tropical Atlantic Ocean. Deep-Sea Res 44:2131-2139

Lewis MR, Cullen JJ, Platt T (1984) Relationships between vertical mixing and photoadaptation of phytoplankton: similarity criteria. Mar Ecol Prog Ser 15:141-149

Lohrenz SE, Arnone RA, Wiesenburg DA, DePalma I (1988a) Satellite detection of transient enhanced primary production in the western Mediterranean Sea. Nature 335: $245-247$

Lohrenz SE, Wiesenburg DA, DePalma IP, Johnson KS, Gustafson DE (1988b) Interrelationships among primary production, chlorophyll, and environmental conditions in frontal regions of the western Mediterranean Sea. DeepSea Res 35:793-810

Longhurst A, Sathyendranath S, Platt T, Caverhill C (1995) An estimate of global primary production in the ocean from satellite radiometer data. J Plankton Res 17:1245-1271

Mague TH, Friberg E, Hughes DJ, Morris I (1980) Extracellular release of carbon by marine phytoplankton: a physiological approach. Limnol Oceanogr 25:262-279

Marañón E, Holligan PM (1999) Photosynthetic parameters of phytoplankton from $50^{\circ} \mathrm{N}$ to $50^{\circ} \mathrm{S}$ in the Atlantic Ocean. Mar Ecol Prog Ser 176:191-203

Minas HJ, Coste B, Le Corre P, Minas M, Raimbault P (1991) Biological and geochemical signatures associated with the water circulation through the Strait of Gibraltar and in the western Alboran Sea. J Geophys Res 96:8755-8771

Mitchell BG, Holm-Hansen O (1991) Observations and modelling of the Antarctic phytoplankton crop in relation to mixing depth. Deep-Sea Res 38:981-1007

Morán XAG, Taupier-Letage I, Vázquez-Domínguez E, Ruiz S, Arin L, Raimbault P, Estrada M (2001) Physical-biological coupling in the Algerian Basin (SW Mediterranean): influence of mesoscale instabilities on the biomass and production of phytoplankton and bacterioplankton. DeepSea Res 48:405-437

Morán XAG, Gasol JM, Pedrós-Alió C, Estrada M (in press) Dissolved and particulate primary production and bacterial production in offshore Antarctic waters during austral summer: coupled or uncoupled? Mar Ecol Prog Ser

Nagata T (2000) Production mechanisms of dissolved organic matter. In: Kirchman DL (ed) Microbial ecology of the oceans. John Wiley \& Sons, New York, p 121-152

Norrman B, Zweifel UL, Hopkinson CS Jr, Fry B (1995) Production and utilization of dissolved organic carbon during an experimental diatom bloom. Limnol Oceanogr 40: 898-907

Packard TT, Minas HJ, Coste B, Martinez R, Bonin MC, Gostan J, Garfield P, Christensen J, Dortch Q, Minas M, Copin-Montegut G, Copin-Montegut C (1988) Formation of the Alboran oxygen minimum zone. Deep-Sea Res 35: 1111-1118

Perkins H, Kinder T, La Violette P (1990) The Atlantic inflow in the western Alboran Sea. J Phys Oceanogr 20:242-263

Platt $\mathrm{T}$ (1985) Phytoplankton production in oligotrophic marine ecosystems: the Mediterranean Sea. In: MoraitouApostolopoulou M, Kiortsis V (eds) Mediterranean marine ecosystems. Plenum Press, New York, p 231-246

Platt T, Sathyendranath S (1988) Oceanic primary production: estimation by remote sensing at local and regional scales. Science 241:1613-1620

Platt T, Gallegos CL, Harrison WG (1980) Photoinhibition of photosynthesis in natural assemblages of marine phytoplankton. J Mar Res 38:687-701 
Platt T, Caverhill C, Sathyendranath S (1991) Basin-scale estimates of oceanic primary production by remote sensing: the North Atlantic. J Geophys Res 96:15147-15159

Rodríguez V (Rapporteur), Bautista B, Blanco JM, Figueroa FL, Cano N, Ruiz J (1994) Hydrological structure, optical characteristics and size distribution of pigments and particles at a frontal station in the Alboran Sea. Working Group 1 Report. Sci Mar 58:31-41

Rodríguez J, Blanco JM, Jiménez-Gómez F, Echevarría F, Gil J, Rodríguez V, Ruiz J, Bautista B, Guerrero F (1998) Patterns in the size structure of the phytoplankton community in the deep fluorescence maximum of the Alboran Sea (southwestern Mediterranean). Deep-Sea Res 45: 1577-1593

Sakshaug E, Bricaud A, Dandonneau Y, Falkowski PG, Kiefer DA, Legendre L, Morel A, Parslow J, Takahashi M (1997) Parameters of photosynthesis: definitions, theory and interpretation of results. J Plankton Res 19:1637-1670

Sathyendranath S, Longhurst AR, Caverhill CM, Platt T (1995) Regionally and seasonally differentiated primary production in the North Atlantic. Deep-Sea Res 42: 1773-1802

Sournia A (1973) La production primaire planctonique en Méditerranée: essai de mise à jour. Bull Étude en Commun Méditerr 5:1-128

Taylor AH, Geider RJ, Gilbert FJH (1997) Seasonal and latitudinal dependencies of phytoplankton carbon-to-chlorophyll ratios: results of a modelling study. Mar Ecol Prog Ser 152:51-66

Thomas JP (1971) Release of dissolved organic matter from natural populations of marine phytoplankton. Mar Biol 11: 311-323

Tintoré J, Gomis D, Alonso S, Parrilla G (1991) Mesoscale

Editorial responsibility: Otto Kinne (Editor),

Oldendorf/Luhe, Germany dynamics and vertical motion in the Alborán Sea. J Phys Oceanogr 21:811-823

Verity P (1981) Effects of temperature, irradiance, and daylength on the marine diatom Leptocylindrus danicus Cleve. II. Excretion. J Exp Mar Biol Ecol 55:159-169

Videau C, Sournia A, Prieur L, Fiala M (1994) Phytoplankton and primary production characteristics at selected sites in the geostrophic Almeria-Oran front system (SW Mediterranean Sea). J Mar Syst 5:235-250

Watanabe Y (1980) A study of the excretion and extracellular products of natural phytoplankton in Lake Nakanuma, Japan. Int Rev Ges Hydrobiol 65:809-834

Webb WL, Newton M, Starr D (1974) Carbon dioxide exchange of Alnus rubra: a mathematical model. Oecologia 17:281-291

Williams PJleB (1993) Chemical and tracer methods of measuring plankton production. ICES Mar Sci Symp 197: 20-36

Williams PJleB, Robinson C, Søndergaard M, Jespersen AM, Bentley TL, Lefèvre D, Richardson K, Riemann B (1996) Algal ${ }^{14} \mathrm{C}$ carbon and total carbon metabolisms. 2. Experimental observations with the diatom Skeletonema costatum. J Plankton Res 18:1961-1974

Wood AM, Van Valen LM (1990) Paradox lost? On the release of energy-rich compounds by phytoplankton. Mar Microb Food Webs 4:103-116

Yentsch CS, Menzel DW (1963) A method for the determination of phytoplankton chlorophyll and phaeophytin by fluorescence. Deep-Sea Res 10:221-231

Zlotnik I, Dubinsky Z (1989) The effect of light and temperature on DOC excretion by phytoplankton. Limnol Oceanogr 34:831-839

Submitted: February 21, 2000; Accepted: August 9, 2000 Proofs received from author(s): February 19, 2001 